

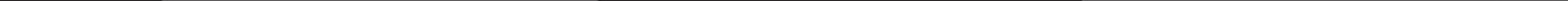




\section{Mercado de trabajo, fuerza de trabajo y economía campesina indígena Nasa en tres municipios del norte del Cauca (Toribío, Jambaló y Caldono)*}

Por Fernando Urrea-Giraldo**

Jairo Alexander Castaño***

Luis Gabriel Quiroz Cortés****

\section{Introducción}

$\mathrm{E}$

1 norte del Cauca es una subregión que presenta una interesante diversidad étnico-racial, así como un importante dinamismo socioeconómico que articula a los municipios entre sí y, cada vez más, con la ciudad de Cali (ver Figura 1). La población Nasa, uno de los grupos étnicos más importantes de los municipios que componen esta subregión, es mayoritaria en Toribío, Jambaló y Caldono ${ }^{1}$. En estos tres municipios los Nasa tienen una larga tradición de organización y

Artículo recibido en julio de 2106.

Artículo aprobado en octubre de 2016.

Este artículo ha sido resultado de una investigación realizada con el equipo indígena de los Proyectos Nasa y Global de los cinco resguardos de los municipios de Toribío y Jambaló, y del resguardo de San Lorenzo de Caldono, con la participación destacada de la socióloga de la comunidad Nasa, Magaly Gualiche Garcés, y de la estadística Clara Isabel Orozco, también Nasa. La Fundación Ford apoyó la realización de la Epen (Encuesta Piloto Experimental Nasa de Unidades Domésticas y Productivas) para los tres resguardos de Toribío (Tacueyó, Toribío y San Francisco) y la Fundación Interamericana del Congreso de los Estados Unidos para el resguardo del municipio de Jambaló en sus tres zonas (alta, media y baja) y el resguardo San Lorenzo de Caldono. 
arraigo territorial que les ha permitido consolidar un tipo de economía campesina indígena articulada al mercado principalmente a través del cultivo de café. Esta producción se realiza en el espacio de cinco resguardos indígenas: tres en Toribío, uno en Jambaló y uno en Caldono. El norte del Cauca y el sur del Valle constituyen a la vez una región interdepartamental cuyo nodo principal es la ciudad de Cali².

Sociólogo, Maestría en Ciencia Política, Profesor Emérito y Titular del Departamento de Ciencias Sociales, Facultad de Ciencias Sociales y Económicas, Universidad del Valle. Email: furreagiraldo@yahoo.com

*** Sociólogo egresado de la Universidad del Valle, coordinador del trabajo de campo y del equipo CIDSE-Univalle-Proyecto Nasa (Toribío), Proyecto Global (Jambaló), Resguardo de San Lorenzo de Caldono (Caldono) y para todos los otros municipios del norte del Cauca con población Nasa en materia de estadísticas indígenas. Email: jacalo16@yahoo.com

**** Economista egresado de la Universidad del Valle, miembro del equipo CIDSE Univalle del norte del Cauca en coordinación con el equipo indígena Nasa local. Email: lugaquir@hotmail.com

1 La subregión norte del Cauca está compuesta por catorce municipios. Según el censo del 2005, en algunos de estos encontramos predominio de población negra/ afrodescendiente, como en Puerto Tejada (97,5\%), Villarrica (96,9\%), Padilla $(96,9 \%)$, Buenos Aires $(68,5 \%)$, Caloto $(62,4 \%)$, Suarez $(58,2 \%)$ y Miranda $(52,7 \%)$; y en otros, predominio de población indígena, como en Jambaló $(98,6 \%)$, Toribío $(95,6 \%)$, Caldono (70,6\%) y Corinto (44,3\%). El municipio de Santander de Quilichao, por su parte, tiene un leve predominio de población étnica (afros e indígenas: $52,7 \%$ ) y un importante contingente de población sin pertenencia étnica (blancos/mestizos: 47,3\%). Para el año 2005 no se tenía información sobre Guachené, debido a que su creación es posterior al censo; de todas formas es un municipio de predominio de población negra/afrodescendiente.

2 Esta regionalización ha sido desarrollada en el estudio "Cali, ciudad región ampliada" de la Alianza de Universidades (Universidades del Valle, Icesi, San Buenaventura, Javeriana y Autónoma de Occidente), que ha contado con recursos de la Fundación Ford, a partir de la metodología propuesta por la Misión Rural (Ocampo, 2015), que se apoya en el concepto de nueva ruralidad. De esta manera pueden analizarse en una misma región municipios con diferentes niveles de urbanidad-ruralidad. La región en mención está conformada por veintiocho municipios: Miranda, Padilla, Guachené, Puerto Tejada, Villa Rica, Caloto, Corinto, Toribío, Jambaló, Caldono, Suárez, Buenos Aires, Morales, Santander de Quilichao, en el departamento del Cauca; y Buenaventura, Dagua, La Cumbre, Vijes, Cerrito, 
Como veremos más adelante, la economía campesina Nasa se caracteriza por una producción para el mercado basada en minifundios y microfundios que utilizan principalmente fuerza de trabajo familiar; además, el autoconsumo constituye una base importante para la reproducción de la unidad doméstica (Kerblay, 1981; Chayanov, 1985).

Al mismo tiempo, los intercambios de fuerza de trabajo a través de la modalidad de "cambio de mano" y "mingas" son muy importantes para la siembra y cosecha de cultivos. La participación de las familias en jornadas de trabajo comunitario en la vereda y en el resguardo aseguran las condiciones generales para la producción agropecuaria de las Unidades Domésticas de Producción Nasa (UDPN).

Si bien es evidente la importancia del asalariamiento y la diversificación de actividades en los resguardos indígenas de estos municipios, los indicadores convencionales del mercado de trabajo no capturan la dimensión laboral de manera adecuada. La multiplicidad y emergencia de actividades - domésticas y económicas - se traduce en una alta tasa de ocupación y desempleo friccional. Conscientes de esta limitación, incluimos el análisis de la fuerza de trabajo: así pues, mediante indicadores como el tiempo destinado a las labores domésticas y al trabajo en la finca, el trabajo familiar no remunerado adquiere una connotación diferente debido a la importancia que tiene en la satisfacción de las necesidades del hogar.

A esta introducción le siguen los aspectos metodológicos y conceptuales de los municipios estudiados. Posteriormente se realiza la caracterización del mercado de trabajo. Después, analizamos el grado de articulación de estos municipios con otras regiones y municipios del país. A continuación analizamos el acceso a tierra, el destino de

Guacarí, Ginebra, Palmira, Cali, Candelaria, Florida, Pradera, Yumbo y Jamundí en el departamento del Valle del Cauca. 
la producción y la fuerza de trabajo, lo cual permite caracterizar el tipo de economía campesina Nasa como una agricultura familiar y estudiar sus interrelaciones con otros municipios del norte del Cauca y con la ciudad de Cali. Finalmente, se presentan las conclusiones más relevantes de esta investigación.

Figura 1. Límites municipales de Toribío, Jambaló y Caldono en la región

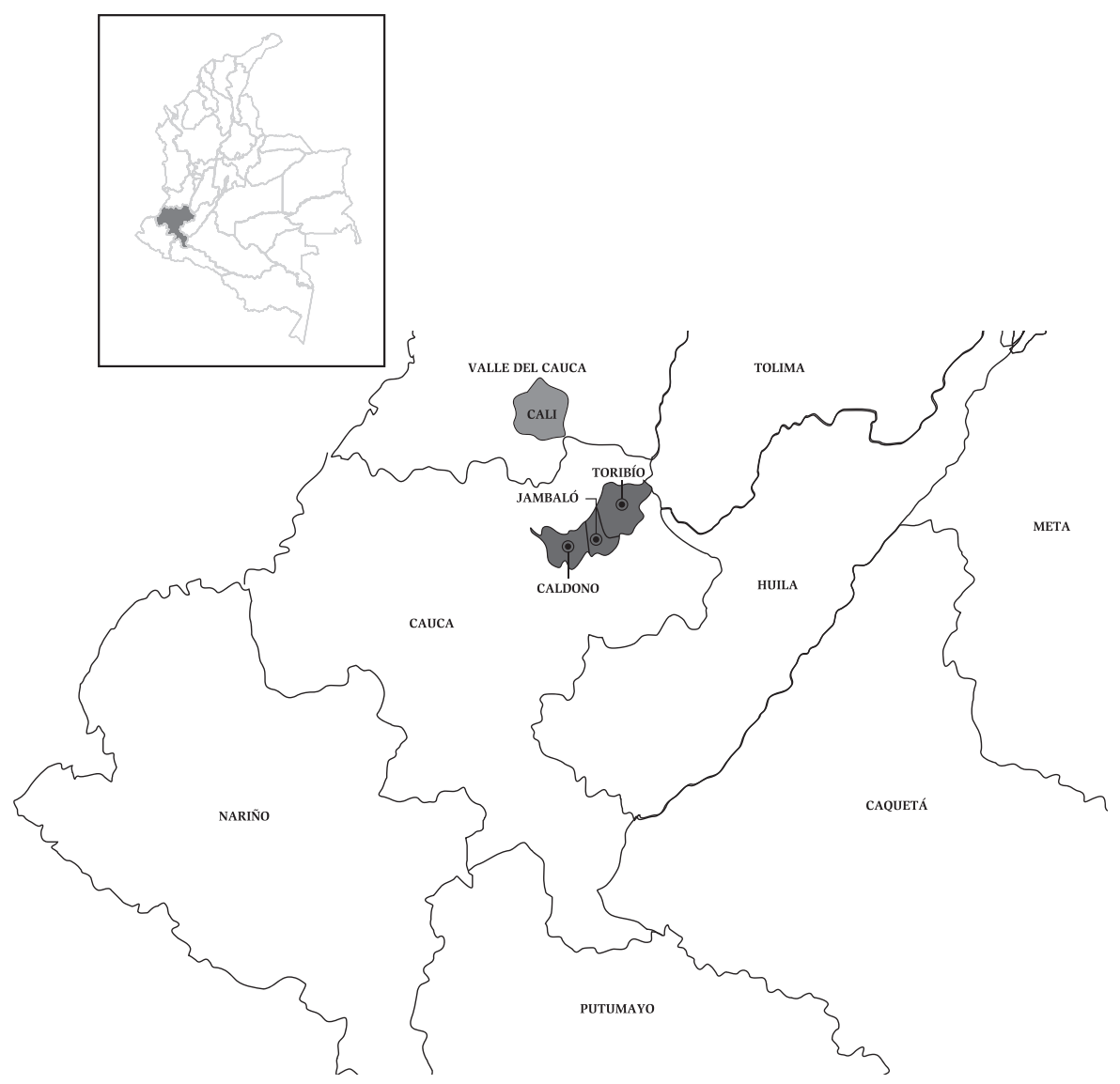




\section{Aspectos metodológicos de la fuente de datos utilizada: la Encuesta Piloto Experimental Nasa de unidades domésticas y productivas, 2014-2015}

La información que se presenta en este artículo tiene como fuente principal los resultados de la Encuesta Piloto Experimental Nasa (Epen) aplicada en los resguardos de Toribío, Tacueyó y San Francisco en el año 2014 y en Jambaló y San Lorenzo de Caldono en 2015.

La muestra para los resguardos de Toribío es probabilística y representativa tanto a nivel municipal como de los tres resguardos; se aplicó en 961 hogares/unidades productivas y el margen de error es inferior al $3 \%$. Las encuestas en Jambaló (300) y Caldono (300) no fueron probabilísticas; se realizó un muestreo aleatorio consecutivo porque se tenía acceso a los censos de población de ambos resguardos e, igualmente, se calcularon factores de expansión para ambas muestras. En Jambaló no se tuvo en cuenta la cabecera municipal por el poco peso poblacional en el total de la población del resguardo.

La encuesta consta de dieciséis módulos sobre distintos ámbitos de la vida de la población Nasa. Los principales módulos indagan por las características demográficas, socioeconómicas (educación, salud, ingresos), de mercado y fuerza de trabajo y sobre acceso a tierra y producción agropecuaria. El marco muestral para la expansión de las tres muestras fueron los censos de los cinco cabildos para todas las unidades domésticas de los resguardos de Tacueyó, Toribío y San Francisco, del municipio de Toribío, el de Jambaló (uno solo que cubre a todo el municipio) y el de San Lorenzo de Caldono.

La aproximación metodológica es estrictamente descriptiva, sin embargo, los indicadores presentados arrojan luces sobre las limitaciones para medir el nivel de actividad laboral en las economías campesinas. Como se indicó previamente en la introducción, un elemento conceptual clave que retomamos en este artículo es la definición de 
nueva ruralidad del Departamento Nacional de Planeación acuñada en la Misión Rural (Ocampo, 2015). Este punto de vista permite observar la complementariedad e interacciones entre los territorios rurales y urbanos.

Según la definición de nueva ruralidad, los criterios fundamentales para definir el grado de ruralidad de los municipios dependen fundamentalmente de la densidad poblacional: la relación entre la población de la cabecera y de fuera de la cabecera es un factor determinante en dicha clasificación. Por consiguiente, se definen cuatro tipos de categorías para los municipios del país: 1) ciudades y aglomeraciones, 2) intermedios, 3) rurales y 4) rurales dispersos. Los municipios de Toribío, Jambaló y Caldono se clasifican dentro de la categoría rural porque su cabecera tiene menos de 25.000 habitantes, más del $70 \%$ de la población se encuentra en la zona "resto” y su densidad poblacional está en el rango de entre diez y cincuenta habitantes por kilómetro cuadrado.

Este enfoque permite entender la ruralidad en términos graduales según el nivel de acceso a servicios públicos, la inserción en el mercado de trabajo, el tipo de actividades económicas y el acceso a mercados de bienes y servicios diferenciados. Por otro lado, nuestro concepto de UDPN se refiere a unidades familiares de producción y de consumo en las que las relaciones de parentesco son las que estructuran las relaciones de producción y de consumo (Chayanov, 1985; Shanin, 1976). Además, contiene las particularidades que caracterizan la situación actual de la población Nasa en los resguardos de Toribío, Jambaló y Caldono.

Entre dichas particularidades, la más importante es el hecho de ser tierra de resguardo desde la Colonia, reconocida desde finales del siglo XIX como territorio del grupo que lo habita y lo administra mediante la institución del Cabildo. De este modo, el territorio es una protección de las unidades domésticas Nasa frente al mercado de tierras y la expan- 
sión de terratenientes y empresarios; sin embargo, debido a que toda la tierra del territorio de los resguardos está asignada, las nuevas UDPN no tienen disponibilidad de tierras $^{3}$.

La segunda particularidad tiene que ver con que los cabildos han jugado un papel determinante en la recuperación de los territorios de resguardo y, además, administran buena parte de las transferencias del Estado central y regional de responsabilidades económicas y sociales (educación y salud, principalmente). Teniendo en cuenta lo anterior, la práctica del trabajo comunitario, que desde el inicio del proceso de recuperación del territorio ha recaído fuertemente sobre la fuerza de trabajo disponible de las unidades domésticas Nasa, se ha ido configurando como una forma de intensificación del trabajo familiar. Y como el trabajo comunitario tiene su soporte en la satisfacción de necesidades culturales del grupo Nasa, la conservación de la cultura propia es también una particularidad constitutiva de las unidades domésticas de producción Nasa.

\section{Mercado de trabajo e inserción de la fuerza de trabajo de los tres municipios de predominio Nasa}

\subsection{Los indicadores convencionales}

Los indicadores del mercado laboral fueron estimados para la población de diez años y más de edad, debido a que Toribío, Jambaló y Caldono son municipios rurales según la clasificación de la Misión Rural (Ocampo, 2015). Este ejercicio posibilita observar los patrones del mercado de trabajo haciendo uso de los indicadores convencionales, pero aplicados en un contexto de econo mía campesina indígena. Sin embargo, meto-

Para un análisis de la situación de tierras en el municipio de Toribío ver: Castaño 2016. 
dológicamente los indicadores calculados para esta sección presentan ciertas restricciones relacionadas con la descripción de la estructura socio-ocupacional en una economía campesina.

En otras palabras, por la presencia de la economía campesina, los criterios de la medición y los resultados en términos del nivel de ocupación, desempleo y participaciones laborales difieren considerablemente frente a los correspondientes a las áreas metropolitanas y al total nacional urbano (Leibovich, Nigrinis y Ramos, 2016) ${ }^{4}$. Este resultado era esperable debido a la estructura de ocupaciones en áreas rurales, donde la división social del trabajo pasa todavía por la esfera de la reproducción de las unidades productivas campesinas, a pesar de la presencia de mano de obra asalariada. Igualmente, en el caso de los Nasa de los resguardos estudiados, el trabajo comunitario en actividades del cabildo, la guardia indígena de las juntas de acción comunal es un factor más que incide en los niveles de ocupación, desempleo y participaciones laborales.

En un escenario de economía rural, la tasa de ocupación revela una prominente inserción en actividades laborales diversas, mientras que el desempleo manifiesta una situación ideal por los valores tan reducidos. Lo anterior es explicado por el conjunto de ocupaciones relacionadas con el trabajo en el hogar, como barrer, cortar leña, cargar agua, cuidar a los animales y el cultivo, etcétera, y no tanto por la profundización de actividades económicas o el crecimiento de la demanda de trabajo. El sesgo urbano de la medición aplicado en un contexto de economía campesina no pondera de forma adecuada las labores destinadas a man-

No obstante, las encuestas de hogares en el sector rural siempre arrojan tasas convencionales de empleo y desempleo más bajas que para el sector urbano. Lo interesante con los resultados para los tres municipios es que algunos de estos indicadores, como el de la tasa de desempleo, bajo la lectura convencional sería apenas friccional, lo que muestra la limitación de una lectura bajo criterios urbanos. 
tener o reproducir la fuerza de trabajo, lo que redunda en incrementos del nivel de ocupación. Esta es la principal limitación que presenta la estimación y lectura de los indicadores del mercado de trabajo en una economía donde el cambio de mano, el cuidado del Tul ${ }^{5}$ y el trabajo no remunerado en el cabildo, la guardia indígena, el hogar o en otros hogares son muy frecuentes ${ }^{6}$.

El Gráfico 1 compara los principales indicadores del mercado de trabajo para los tres municipios. Jambaló y Toribío presentan una mayor proporción de personas en edad de trabajar (PET), 79,5\% en ambos casos, en comparación con Caldono, con un 75,6\%. De modo similar, Caldono revela la menor tasa global de participación (TGP) para ambos sexos: $55,1 \%$ frente a $65,3 \%$ de Jambaló y $66,9 \%$ en Toribío. Esto significa una moderada presión demográfica sobre el mercado de trabajo en Caldono, mientras que en Toribío y Jambaló ocurre lo opuesto.

Al desagregar por sexo se evidencian diferencias en las participaciones laborales. En primera instancia, los hombres de Toribío (79,7\%), Jambaló $(76 \%)$ y Caldono $(69,7 \%)$ se encuentran más volcados al mercado de trabajo que las mujeres, siendo los de Toribío los que expresan la mayor integración laboral. Para el caso de las mujeres, las de Jambaló y Toribío manifiestan participaciones más elevadas $(54,5 \%$ y $54,1 \%$ respectivamente) que las de Caldono (41\%).

5 En términos generales el Tul equivale a la huerta casera campesina y representa una forma de trabajo productivo en el hogar Nasa. Para los Nasa, el Tul está en relación directa con la necesidad de recuperar los saberes ancestrales sobre las propiedades curativas y nutritivas de las plantas.

$6 \quad$ Pero al igual que la categoría “cuenta propia”, la de trabajo familiar no remunerado en el hogar o en otros hogares tiene un sentido diferente al contexto urbano, ya que en este caso expresa más el fenómeno del intercambio de fuerza de trabajo entre las unidades domésticas de una vereda y veredas contiguas (cuando se trata de trabajo en otros hogares); es decir, el mecanismo de "cambio de mano" para los diversos cultivos a lo largo del año. Se trata de una modalidad clásica de una economía campesina. 
Llama la atención la reducida participación laboral en Caldono, lo cual evidencia diferencias muy marcadas en la estructura laboral y de ocupaciones frente a Toribío y Jambaló. Esta baja participación laboral se debe a la elevada inactividad laboral (ver gráfico 11). Según la Epen, la semana anterior a la visita a este municipio el 19,2\% de las personas de diez y más años de edad estaban dedicadas a los oficios del hogar y el $24,3 \%$ a estudiar. En Toribío, por su parte, estos porcentajes fueron del 15,6\% en oficios del hogar y el 19,3\% estudiando, mientras que en Jambaló el 13,3\% se dedicaba a oficios del hogar y el 20,9\% a estudiar (ver anexo I).

Gráfico 1. Tasas global de participación, de ocupación, de inactividad y desempleo por sexo en los tres municipios de predominio Nasa en norte del Cauca, población de 10 años y más de edad.

Encuesta Piloto Experimental Nasa, 2014-2015

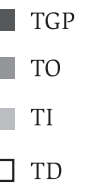

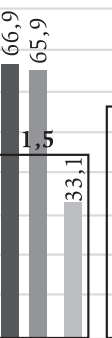

Total

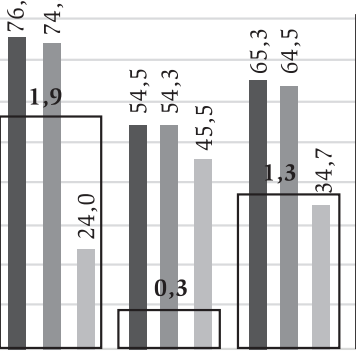

Hombre

Total
Mujer

Jambaló
2,7

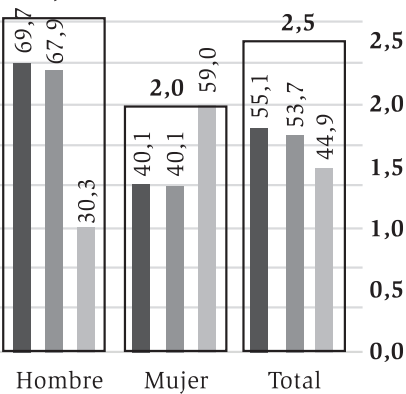

0,3 5

Toribío

Caldono

\section{0}

\section{, 5} 0 , 5 0 
En Toribío, la tasa de personas ocupadas fue de 65,9\% , 1,4 y 12,2 puntos porcentuales pp por encima de la tasa de ocupación (TO) de Jambaló $(64,5 \%)$ y Caldono $(55,1 \%)$ respectivamente. La brecha de género en el mercado de trabajo es mucho más marcada en Caldono que en los otros municipios: el diferencial entre la tasa de ocupación de hombres y mujeres llega a ser de 27,7 pp. En el caso de Toribío la brecha es ligeramente inferior (26,3 pp) y resulta mucho más tenue en Jambaló 20,2 pp. El factor demográfico influye en el hecho de que Caldono presente la mayor inactividad laboral femenina asociada a la dedicación a las actividades domésticas y al peso de la población estudiantil.

En términos de las ocupaciones, las actividades agropecuarias concentran gran parte de estas. Así, el 78,9\% de los ocupados de Jambaló realizan labores de precultivo, siembra, cultivo, cosecha, poscosecha y otras actividades agropecuarias, mientras que para Toribío representan el 68,5\% y en Caldono el 64,6\% de los ocupados (ver Anexo II) ${ }^{7}$.

Según sexo, los hombres de Toribío, con un 79,1\%, presentan la TO más elevada relativamente (en Jambaló son el 74,5\% y en Caldono el $67,9 \%)$. El tipo de ocupaciones de los hombres indica un patrón muy cercano al del total de cada municipio; es decir, las actividades agropecuarias concentran la mayor parte de la fuerza de trabajo masculina: el 79,4\% de los ocupados de Jambaló, el 71,8\% en Toribío y el 70,6\% en Caldono (ver Anexo II).

Estos datos varían debido a los diferentes periodos de precosecha, cosecha y poscosecha. Como la Encuesta Piloto Experimental Nasa para Toribío se hizo en precosecha, en este municipio las ocupaciones relacionadas con el periodo posterior a la cosecha fueron muy reducidas $(0,4 \%)$, a diferencia de Jambaló $(48,4 \%)$ y Caldono (32\%), municipios en donde se realizó la encuesta precisamente en ese periodo. Al mismo tiempo, en Toribío la etapa anterior al cultivo registra el mayor porcentaje $(32,5 \%)$, frente a Caldono $(6,3 \%)$ y Jambaló $(1,3 \%)$. Esto muestra cómo la estacionalidad y ritmos de los cultivos afectan las respuestas a las preguntas sobre las ocupaciones rurales en el mercado de trabajo, dependiendo del periodo del año en que se levanta la información. 
La situación de las mujeres evidencia que son las de Jambaló, con un $54,3 \%$, las que tienen la tasa de ocupación más elevada en relación con las de Toribío (52,7\%) y de Caldono (40,1\%). La distribución de las ocupaciones femeninas permite observar un patrón similar al masculino: en Jambaló el 77,9\% de las mujeres se dedica a actividades agropecuarias, en Toribío el 64\% y en Caldono el 54,9\% de las ocupadas (ver anexo II). Asimismo, las ocupaciones relacionadas con la venta y el comercio, así como los trabajos de servicios personales, tienen una participación importante en Toribío (13,3\% y 4,7\% respectivamente) y Caldono $(12,4 \%$ y $11,1 \%)$, y en menor grado en Jambaló $(4,7 \%$ y $2,2 \%$ ) (ver Anexo II). Estos hallazgos muestran la mayor diversificación de actividades en el mercado de trabajo local en Toribío y Caldono.

La tasa de desempleo (TD) es casi friccional o muy reducida en los tres municipios: $2,5 \%$ en Caldono, $1,5 \%$ en Toribío y 1,3\% en Jambaló. La lectura convencional de este indicador no resulta convincente; más bien, puede decirse que la reducida tasa de desempleo evidencia la importancia que tiene la distribución de las labores o actividades en las zonas rurales.

Según la Epen, la proporción de personas que al momento de la encuesta buscaba trabajo es muy baja en los tres municipios: Jambaló y Toribío registran $0,6 \%$ y $0,7 \%$ respectivamente, y Caldono 1,3\%. Lo anterior, y teniendo en cuenta el porcentaje de los que se encuentran trabajando (52,9\% en Caldono y $62 \%$ en Toribío y Jambaló), permite apreciar el efecto que tiene la diversidad de actividades de cualquier tipo -ya sean remuneradas o no- sobre la tasa de ocupación laboral en las zonas rurales.

En el año 2014, los datos totales de los cuatro trimestres de la Gran Encuesta Integrada de Hogares (Geih) del DANE muestran que la TGP de la zona rural para el total nacional fue de $58,1 \%$, un resultado muy cercano al valor arrojado por la Epen para el resguardo de Caldono 
$(55,1 \%)$ y muy por debajo de la tasa en los resguardos de Toribío $(66,9 \%)$ y Jambaló $(65,3 \%)$. En el indicador tasa de ocupación se presenta un comportamiento similar: la Epen muestra que Caldono está más cercano al promedio nacional de la zona rural $(53,7 \%$ y 54,8\%, respectivamente), mientras que Toribío (65,9\%) y Jambaló $(64,5 \%)$ están más de diez puntos porcentuales por encima del promedio nacional según datos de la Geih. En la tasa de desempleo tenemos que los resguardos indígenas tenían una menor tasa de desempleo que la población total de la zona rural según la Geih (5,7\%).

En síntesis, a pesar de las limitaciones del módulo de mercado laboral, los resultados son consistentes y permiten comprender el sesgo interpretativo y las restricciones de su lectura convencional en las economías campesinas.

\subsection{Posición socio-ocupacional de los presentes y ausentes}

La Epen indagó por la actividad económica de las personas ausentes y presentes en el hogar. Por ausente entiéndase aquella persona que pertenece a la unidad doméstica u hogar pero que al momento de la encuesta se encontraba en otro sitio distinto; el periodo de referencia para considerar ausente a una persona corresponde a los últimos seis meses.

\subsubsection{Miembros de las unidades domésticas presentes}

El trabajador por cuenta propia tiene la mayor participación en la posición ocupacional, siendo Caldono el municipio que registra el porcentaje de trabajadores por cuenta propia más elevado $(70,9 \%)$, al cual le sigue Jambaló (59,9\%) y por último Toribío (44,2\%) (Ver Anexo III). Cabe señalar que esta categoría se refiere principalmente al pequeño productor indígena-campesino. 
La segunda categoría en importancia corresponde a la de jornalero o peón, cuyos porcentajes se distribuyen de la siguiente manera: 25,2\% en Toribío, 13,6\% en Caldono y 11,9\% en Jambaló. El trabajo sin remuneración en el hogar o en otros hogares también muestra una participación importante; en el caso de Jambaló $(22,1 \%$ ) y Toribío $(17,3$ \% ) este tipo de trabajadores pesan mucho más en la distribución ocupacional si se comparan con Caldono $(3,6 \%)$.

Posiblemente, el acceso a la tierra en este tipo de economías determina fuertemente la distribución socio-ocupacional. Esto parece factible ya que más adelante veremos que la escasez de tierra en Toribío tiene correlato con el mayor peso de las actividades asalariadas agropecuarias (como jornaleros) y de otras relacionadas con el comercio y los servicios. Por otro lado, en Caldono la disponibilidad de tierra hace posible la mayor participación de la fuerza de trabajo bajo la modalidad de cuenta propia.

Siguiendo con el análisis de las ocupaciones, el obrero o empleado del cabildo o empresa comunitaria y el trabajador de empresa privada muestran proporciones más significativas en Toribío $(7,3 \%$ y 1,5\%, respectivamente) en relación con Jambaló (3,7\% y 0,3\%) y Caldono $(2,0 \%$ y $1,4 \%)$. Por su parte, el trabajador o empleado del gobierno tiene mayor importancia en Caldono $(4,7 \%)$ que en Toribío $(2,9 \%)$ y Jambaló (1,5\%). Nuevamente, si observamos el grado de asalariamiento vía jornaleros o peones y la proporción de trabajadores en empresas privadas o en el gobierno, se evidencia una mayor articulación a dinámicas laborales capitalistas en el caso de Toribío (ver Anexo III).

Con el empleo doméstico ocurre lo siguiente: en Caldono está la mayor proporción de estas(os) trabajadoras(es) (3,6\%) frente a Toribío (1,4\%) y Jambaló $(0,6 \%)$. En el caso de los patrones o empleadores, estos no tienen mayor importancia en la estructura ocupacional -en ninguno de los municipios llega al 1\%-. La posición ocupacional corrobora la existencia de una economía campesina al detectar la importancia que tiene 
el trabajo familiar sin remuneración, el trabajo asalariado en la finca, en empresa privada o en el gobierno, los pocos empleadores y la sobrerrepresentación de la categoría cuenta propia.

Gráfico 2. Distribución porcentual de la posición ocupacional por sexo para miembros presentes y ausentes de la unidad doméstica que están en el mercado de trabajo como ocupados, en los tres municipios de predominio Nasa, Encuesta Piloto Experimental Nasa 2014-2015.
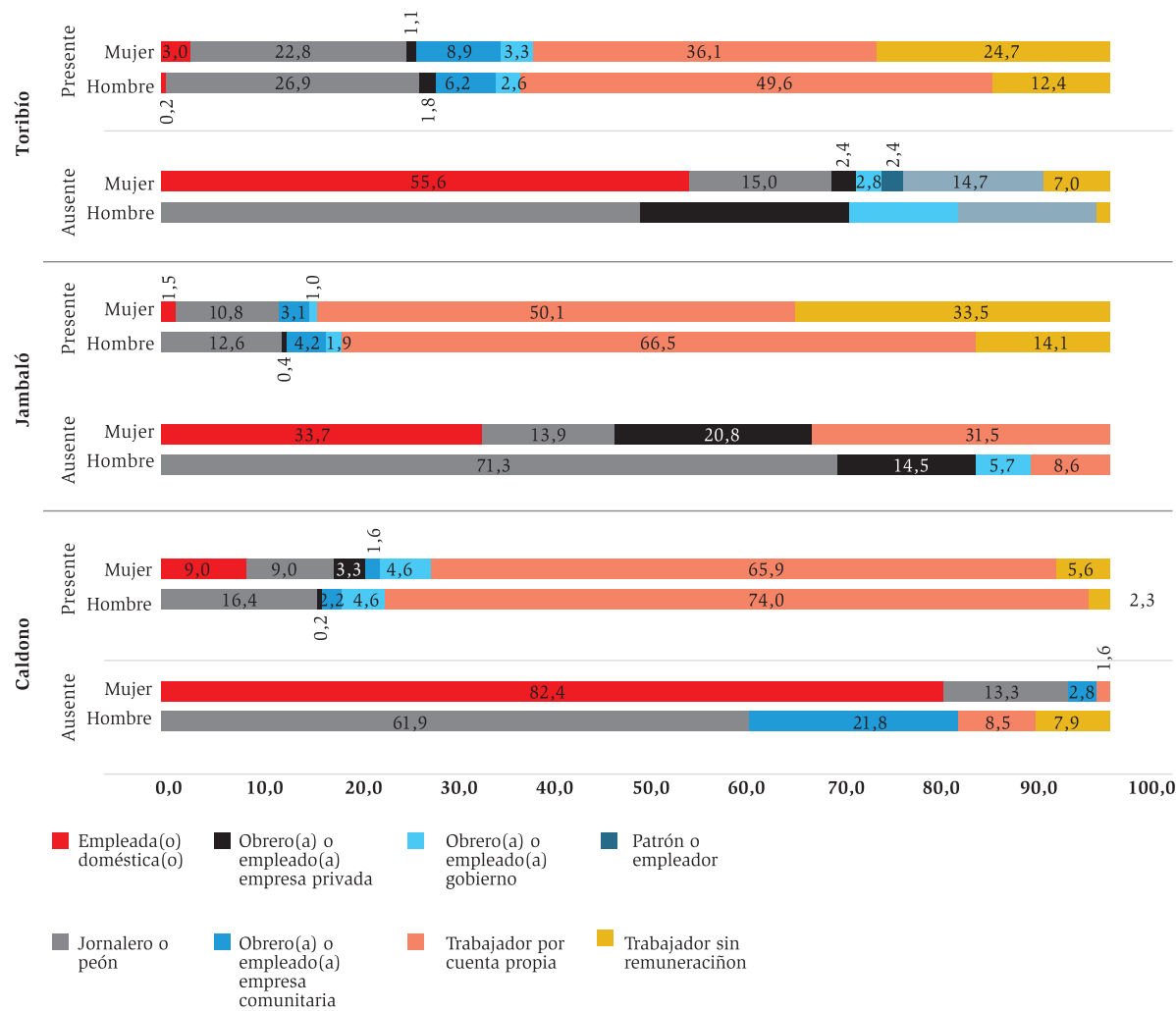
Según sexo, los hombres revelan un patrón similar al total municipal: en Caldono se registra el mayor porcentaje de trabajadores por cuenta propia (74\%), por encima de Jambaló (66,8\%) y Toribío (49,6\%); los de este último municipio manifiestan el mayor grado de asalariamiento (26,9\% ) -16,4\% en Caldono y 12,6\% en Jambaló-; y los de Jambaló tienen una mayor participación en trabajos en otros hogares y en el mismo hogar no remunerados $(14,1 \%)-12,4 \%$ en Toribío y $2,3 \%$ en Caldono- (ver Gráfico 2).

Para el caso de las mujeres, el mayor porcentaje de trabajadoras por cuenta propia lo ostenta Caldono $(65,9 \%)-50,1 \%$ en Jambaló y 36,1\% en Toribío-. Otra categoría relevante corresponde a las trabajadoras sin remuneración; así, en Jambaló el 33,5\% de las mujeres trabaja sin remuneración, el $24,7 \%$ en Toribío y el $5,6 \%$ en Caldono. Entre tanto, las jornaleras de Toribío (22,8\%) presentan una mayor participación en relación con las de Jambaló (10,8\%) y Caldono (9,0\%). Nótese que el servicio doméstico en Caldono (9,0\%) exhibe la proporción de empleadas más elevada versus 3,0\% para Toribío y 1,5\% para Jambaló. Finalmente, la distribución ocupacional evidencia que en las zonas rurales, detrás de los diferentes roles o labores, hay un reparto o asignación tradicional que pasa por la categoría de género. Se evidencia también así una importante inserción laboral de las mujeres en distintas actividades económicas, incluso como trabajadoras sin remuneración en la finca del hogar o de otros hogares.

\subsubsection{Miembros de las unidades domésticas ausentes}

Buena parte de los ocupados ausentes de Jambaló trabaja como peones o jornaleros $(50,6 \%)$, a diferencia de los de Toribío (37\%) y Caldono $(26,5 \%)$. Para el caso de Caldono, es muy importante el empleo doméstico $(60 \%)$, que supera por mucho a la población de trabajadoras(es) domésticas(os) de Toribío $(21,1 \%)$ y de Jambaló $(12,1 \%)$. En términos relativos, los trabajadores de Toribío (14,6\%) y Jambaló (16,8\%) se encuentran más vinculados a empresas privadas que los de Caldono, 
donde no se encontraron trabajadores ausentes vinculados en empresas privadas (ver Anexo III).

Considerando la variable sexo, los hombres se encuentran principalmente laborando como jornaleros o peones de otras fincas: en Jambaló la proporción representa el 71,3\%, en Caldono llega a 61,9\% y en Toribío a 50,4\%. Por otro lado, los trabajadores en empresas privadas también tienen una participación importante en el caso de Toribío (22\%) y Jambaló (14,5\%), pero, como se vio, no en Caldono. Los trabajadores por cuenta propia y los empleados del gobierno igualmente tienen proporciones no despreciables con respecto al total (ver Gráfico 2).

La situación de las mujeres ausentes muestra un porcentaje similar de mujeres asalariadas/jornaleras: en Toribío la proporción es del 15\%, en Jambaló $13,9 \%$ y en Caldono 13,3\%. No obstante, con relación al trabajo doméstico se presentan diferenciales muy profundos, pues si bien más de la mitad de las mujeres ausentes de Toribío $(55,6 \%$ ) y una tercera parte de las de Jambaló $(33,7 \%)$ se encuentran vinculadas laboralmente como empleadas del servicio doméstico, estos porcentajes resultan modestos frente a la proporción de trabajadoras domésticas de Caldono (82,4\%) (ver Gráfico 2). En otras palabras, principalmente las mujeres de Caldono, y en menor medida las de Toribío y Jambaló, constituyen el ejército de reserva de empleadas del servicio doméstico residentes para ciudades como Cali, Popayán y Bogotá, pero principalmente para Cali ${ }^{8}$.

En un portal de libre acceso en internet se presenta el mapa de departamentos colombianos y se calcula un índice de empleados del servicio doméstico en condición de residentes, que es igual al cociente entre el número de "empleados de servicio" -registrados en el censo 2005 y que por tanto residen y son censados en la casa donde trabajan- y la total de la población. Este indicador solo se estima para las cabeceras urbanas municipales. Para profundizar más sobre la temática, revisar el siguiente enlace: http://finiterank.github.io/censo/empleadas.html. 


\subsection{Distribución según ramas de la actividad económica}

La mayor parte de los ocupados en Jambaló, Toribío y Caldono se encuentran en el sector agropecuario, lo que marca el carácter rural de estos municipios. De acuerdo con lo anterior, Jambaló presenta el mayor porcentaje de trabajadores agropecuarios, registrando el 78,2\%, para Toribío y Caldono las participaciones son 74,7\% y 65,4\% respectivamente (ver Anexo IV). De otro lado, ramas de actividad como el sector de la construcción, comercio y ventas, y las ocupaciones ligadas a la administración pública y servicios sociales demuestran participaciones porcentuales no despreciables.

Esta tendencia se mantiene al analizar las ramas de actividad según sexo. En consecuencia, los hombres de Toribío y Jambaló tienen proporciones similares de ocupados en el sector agropecuario $(79,6 \%$ y $79,2 \%$ respectivamente) que resultan mayores en comparación con las de Caldono (72,0\%). Del mismo modo, el sector de la construcción resulta importante para los hombres de estos municipios: el 9,9\% de los ocupados de Caldono se desempeña en este sector, frente al 5,8\% de Jambaló y al 4,2\% de Toribío. Las actividades relacionadas con el comercio y las ventas, así como la educación, servicios sociales y ad-

Cali es una de las ciudades con mayor participación de mujeres en el servicio doméstico que trabajan como "internas". La mayor parte de ellas son mujeres indígenas y negras procedentes, entre otras, del norte del Cauca. Según la Encuesta de Empleo y Calidad de Vida de Cali, 2012-2013 del Ministerio de Trabajo, el 57\% de las empleadas domésticas en Cali son afrodescendientes e indígenas. En los últimos 15 años, a raíz del incremento del empleo para las mujeres negras en las empresas de la zona franca del norte del Cauca en actividades de maquila, se ha abierto para las mujeres indígenas aún más el empleo doméstico en Cali, en buena medida como trabajadoras "internas". Caldono hoy en día podría ser uno de los municipios que más exporta mujeres para el servicio doméstico a la ciudad de Cali. En los últimos 10 años una ola de migrantes indígenas Nasa, especialmente de Caldono, han llegado a la ciudad y una parte de ellos ha conformado un barrio de invasión en la ladera de Cali, en la comuna 18. Todas las mujeres de esta invasión trabajan en el empleo doméstico. 
ministración pública, son sectores donde se encuentra trabajando una proporción considerable de hombres.

La situación de las mujeres expone un patrón semejante al de los hombres; en otras palabras, la mayoría de las mujeres ocupadas se desempeña principalmente en el sector agropecuario (76,8\% en Jambaló, 67,3\% en Toribío y 55,2\% en Caldono) y, en segundo lugar, como empleadas del servicio doméstico (11,6\% para Caldono, 5,3\% en Toribío y 4,6\% en Jambaló).

\section{Articulación de la fuerza de trabajo indígena a la subregión sur del Valle y norte del Cauca}

4.1. Articulación de trabajadores en calidad de asalariados en otras fincas, hogares, fábricas o negocios

La Epen permite calcular el porcentaje de hombres y mujeres Nasa que en los doce meses anteriores a la encuesta se insertaron en el mercado laboral como trabajadores(as) asalariados(as) en otras fincas, en hogares, en fábricas o en negocios, tanto al interior del resguardo como por fuera de este. Con esta aclaración, nos enfocamos principalmente en los trabajadores que salieron del territorio con la intención de observar el grado de articulación vía mercado de trabajo.

El Cuadro 1 muestra que el $40 \%$ de la población de diez años y más de los resguardos de Toribío realizó algún trabajo asalariado en los últimos doce meses, lo cual pone en evidencia la importan- cia del asalariamiento en estos hogares y una mayor inserción en el mercado laboral local y regional. 
Cuadro 1. Proporción de personas que en los últimos 12 meses dedicaron tiempo al trabajo como independientes o por cuenta propia distintos a los de la finca según sexo, Encuesta Piloto Experimental Nasa.

\begin{tabular}{|c|c|c|c|c|c|c|c|c|}
\hline \multicolumn{9}{|c|}{ Jambaló } \\
\hline \multirow[t]{2}{*}{ Sexo } & \multicolumn{3}{|c|}{ Si } & \multicolumn{3}{|c|}{ No } & \multicolumn{2}{|c|}{ Total } \\
\hline & $\mathbf{N}$ & $\% \mathrm{Col}$ & $\%$ Fil & $\mathbf{N}$ & $\%$ Col & $\%$ Fil & $\mathbf{N}$ & $\%$ Fil \\
\hline Hombre & 1270 & 37.6 & 19.9 & 5100 & 55.6 & 80.1 & 6370 & 50.7 \\
\hline Mujer & 1038 & 30.7 & 16.8 & 5151 & 56.2 & 83.2 & 6189 & 49.3 \\
\hline Total & 2309 & 68.3 & 18.4 & 10250 & 111.8 & 81.6 & 12559 & 100.1 \\
\hline
\end{tabular}

\begin{tabular}{|c|c|c|c|c|c|c|c|c|}
\hline \multicolumn{9}{|c|}{ Caldono } \\
\hline \multirow[t]{2}{*}{ Sexo } & \multicolumn{3}{|c|}{ Si } & \multicolumn{3}{|c|}{ No } & \multicolumn{2}{|c|}{ Total } \\
\hline & $\mathbf{N}$ & $\% \mathrm{Col}$ & $\%$ Fil & $\mathbf{N}$ & $\%$ Col & $\%$ Fil & $\mathbf{N}$ & $\%$ Fil \\
\hline Hombre & 765 & 30.3 & 16.8 & 3785 & 55.5 & 83.2 & 4550 & 48.7 \\
\hline Mujer & 574 & 22.8 & 12.0 & 4222 & 61.9 & 88.0 & 4796 & 51.3 \\
\hline Total & 1339 & 53.1 & 14.3 & 8007 & 117.3 & 85.7 & 9346 & 100.0 \\
\hline
\end{tabular}

\begin{tabular}{|c|c|c|c|c|c|c|c|c|}
\hline \multicolumn{9}{|c|}{ Toribío } \\
\hline \multirow[t]{2}{*}{ Sexo } & \multicolumn{3}{|c|}{ Si } & \multicolumn{3}{|c|}{ No } & \multicolumn{2}{|c|}{ Total } \\
\hline & $\mathbf{N}$ & $\%$ Col & $\%$ Fil & $\mathbf{N}$ & $\% \mathrm{Col}$ & $\%$ Fil & $\mathbf{N}$ & $\%$ Fil \\
\hline Hombre & 2428 & 53.1 & 17.7 & 11258 & 49.6 & 82.3 & 13686 & 50.1 \\
\hline Mujer & 2144 & 46.9 & 15.8 & 11461 & 50.4 & 84.2 & 13605 & 49.9 \\
\hline Total & 4572 & 100.0 & 16.8 & 22719 & 100.0 & 83.2 & 27291 & 100.0 \\
\hline
\end{tabular}

Los porcentajes de personas que realizaron trabajo asalariado en Jambaló $(26,9 \%)$ y Caldono (27\%) son inferiores a los de Toribío, lo que posiblemente esté aso- ciado con el mayor acceso a tierra y la extensión de los predios en estos resguardos. De todas formas, tienen porcentajes importantes de personas que han realizado actividades laborales asalariadas.

Por sexo encontramos que los hombres de todos los resguardos tienen el mayor porcentaje de dedicación de tiempo a trabajos asalariados y, 
como era de esperar, son los hombres y las mujeres de Toribío las que presentan mayor inserción laboral como asalariadas.

Por otro lado, en cada uno de los resguardos seleccionados se calculó el porcentaje de población que realizó trabajo asalariado por fuera del resguardo en los últimos doce meses. De este modo, tenemos que Jambaló es el municipio con mayor proporción de migrantes laborales en actividades asalariadas con un porcentaje de $23,4 \%$, seguido de Caldono con $13,9 \%$ y finalmente Toribío con un $10 \%$ de asalariados por fuera del resguardo.

\section{Gráfico 3. Lugares de destino de las personas que en los últimos 12 meses dedicaron tiempo al trabajo asalariado. Encuesta Piloto Experimental Nasa}

Toribío

Jambaló

Caldono

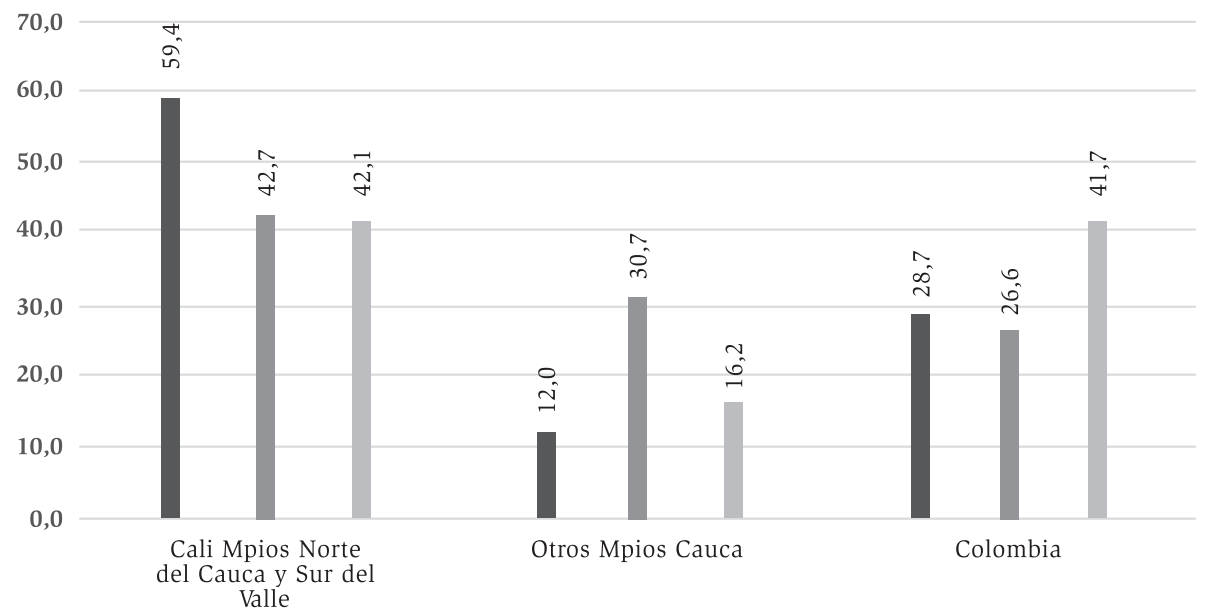


El Gráfico 3 nos muestra que en todos los resguardos el principal destino de la migración laboral en actividades asalariadas es Cali y los municipios de la región norte del Cauca y sur del Valle. Los resguardos de Toribío se destacan con el mayor porcentaje de inserción laboral en el mercado laboral de Cali y la región con un 59,4\% de migrantes laborales en estos municipios, Jambaló muestra una mayor inserción laboral en otros municipios del Cauca $(30,7 \%$ versus $12 \%$ en Toribío y 16,2 en Caldono) y Caldono se destaca por una migración e inserción laboral alta $(41,7 \%)$ en otros municipios de Colombia (por ejemplo Medellín, Bogotá, Manizales, entre otros).

Gráfico 4. Lugares de destino de las personas que en los últimos 12 meses dedicaron tiempo al trabajo asalariado según sexo. Encuesta Piloto Experimental Nasa

Cali Mpios Norte del Cauca y Sur del Valle

Colombia

Otros Mpios Cauca

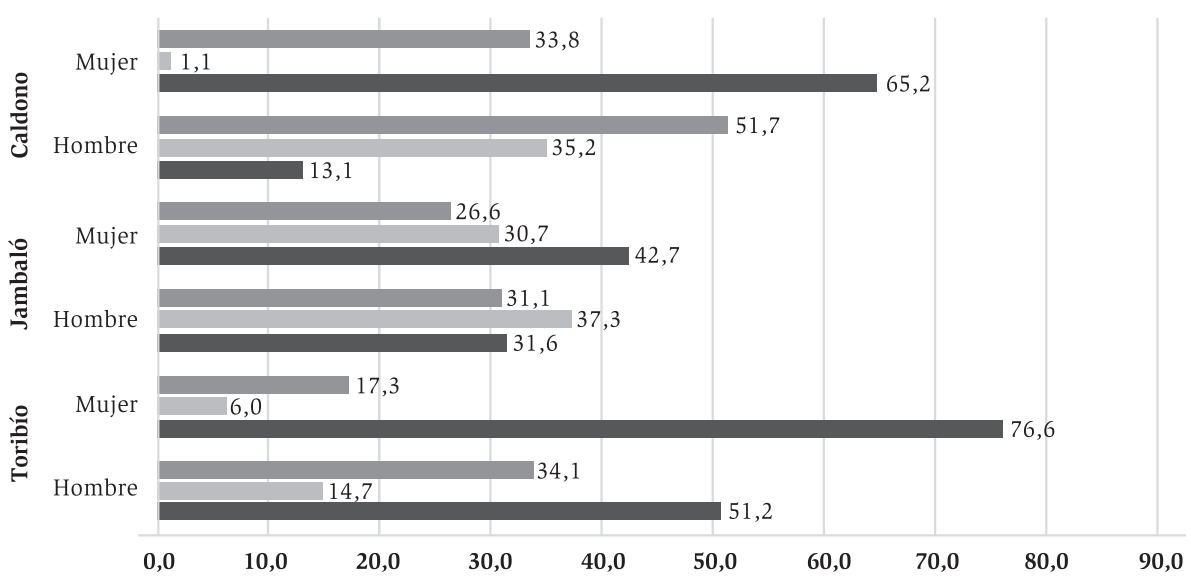


Teniendo en cuenta lo anterior, el Gráfico 4 muestra el lugar de destino de la población -según sexo- que dedicó tiempo a las actividades asalariadas en los últimos doce meses. Para ello se clasifican en tres grandes grupos de municipios: Cali y los municipios de la región norte del Cauca y sur del Valle', otros municipios del Cauca y otros municipios de Colombia.

Por sexo encontramos diferencias interesantes en los resguardos estudiados (ver Gráfico 4). En primer lugar, llama la atención la gran importancia de la migración laboral femenina hacia Cali y los municipios del norte del Cauca y Sur del valle: en el caso de las mujeres de Toribío, estos municipios son el destino del $76,6 \%$ de mujeres, en Caldono del 65,2\% y en Jambaló del 42,7\% de las migrantes laborales. Como se analizó en el apartado sobre las ocupaciones de las mujeres presentes y ausentes de los resguardos, estos porcentajes están estrechamente relacionados con la fuerte inserción laboral de las mujeres Nasa en el empleo doméstico en hogares de la ciudad de Cali. Como hipótesis puede decirse que las economías campesinas indígenas del norte del Cauca son un reservorio de mano de obra femenina para el servicio doméstico en la ciudad de Cali, con lo cual se configura un "ejército de reserva" para los hogares caleños a precios de mercado favorables.

Los hombres de los resguardos de Toribío $(51,2 \%$ ) son los que tienen la mayor articulación con el mercado laboral en Cali y la región; como veíamos en el apartado de las ocupaciones, esta inserción laboral se da sobre todo en condición de jornaleros y obreros. Para los hombres de Caldono $(51,7 \%)$ y Jambaló $(37,3 \%)$ es más importante el mercado laboral de otros municipios del Cauca como Popayán, Piendamó y Argelia. Es muy importante resaltar que los hombres Nasa de los cinco resguardos tienen una migración laboral importante hacía otros municipios de Colombia (Neiva, Bogotá, Medellín, entre otros).

9 Como ya se mencionó al inicio del artículo, esta regionalización hace parte del proyecto “Cali Ciudad región ampliada” de la Alianza de Universidades. 


\subsection{Articulación de trabajadores en calidad de independientes o cuenta propia (distintos al trabajo en la finca)}

En este apartado analizaremos el porcentaje de hombres y mujeres Nasa que en los doce meses anteriores a la encuesta se insertaron en el mercado laboral como trabajadores(as) independientes o cuenta propia en actividades distintas a la finca (dentro y fuera del resguardo). También se incluye el porcentaje y los principales destinos de los(as) trabajadores(as) que realizaron este tipo de trabajos por fuera del territorio de resguardo.

Cuadro 2. Proporción de personas que en los últimos 12 meses dedicaron tiempo al trabajo como independientes o por cuenta propia, distintos a los de la finca según sexo, Encuesta Piloto Experimental Nasa

\begin{tabular}{|c|c|c|c|c|c|c|c|c|}
\hline \multicolumn{9}{|c|}{ Jambaló } \\
\hline \multirow[t]{2}{*}{ Sexo } & \multicolumn{3}{|c|}{ Si } & \multicolumn{3}{|c|}{ No } & \multicolumn{2}{|c|}{ Total } \\
\hline & $\mathbf{N}$ & $\% \mathrm{Col}$ & \%Fil & $\mathbf{N}$ & $\% \mathrm{Col}$ & $\%$ Fil & $\mathbf{N}$ & \%Fil \\
\hline Hombre & 1270 & 37.6 & 19.9 & 5100 & 55.6 & 80.1 & 6370 & 50.7 \\
\hline Mujer & 1038 & 30.7 & 16.8 & 5151 & 56.2 & 83.2 & 6189 & 49.3 \\
\hline Total & 2309 & 68.3 & 18.4 & 10250 & 111.8 & 81.6 & 12559 & 100.1 \\
\hline \multicolumn{9}{|c|}{ Caldono } \\
\hline \multirow[t]{2}{*}{ Sexo } & \multicolumn{3}{|c|}{ Si } & \multicolumn{3}{|c|}{ No } & \multicolumn{2}{|c|}{ Total } \\
\hline & $\mathbf{N}$ & $\% \mathrm{Col}$ & $\%$ Fil & $\mathbf{N}$ & $\% \mathrm{Col}$ & $\%$ Fil & $\mathbf{N}$ & $\%$ Fil \\
\hline Hombre & 765 & 30.3 & 16.8 & 3785 & 55.5 & 83.2 & 4550 & 48.7 \\
\hline Mujer & 574 & 22.8 & 12.0 & 4222 & 61.9 & 88.0 & 4796 & 51.3 \\
\hline Total & 1339 & 53.1 & 14.3 & 8007 & 117.3 & 85.7 & 9346 & 100.0 \\
\hline \multicolumn{9}{|c|}{ Toribío } \\
\hline \multirow[t]{2}{*}{ Sexo } & \multicolumn{3}{|c|}{ Si } & \multicolumn{3}{|c|}{ No } & \multicolumn{2}{|c|}{ Total } \\
\hline & $\mathbf{N}$ & $\% \mathrm{Col}$ & \%Fil & $\mathbf{N}$ & $\% \mathrm{Col}$ & $\%$ Fil & $\mathbf{N}$ & $\%$ Fil \\
\hline Hombre & 2428 & 53.1 & 17.7 & 11258 & 49.6 & 82.3 & 13686 & 50.1 \\
\hline Mujer & 2144 & 46.9 & 15.8 & 11461 & 50.4 & 84.2 & 13605 & 49.9 \\
\hline Total & 4572 & 100.0 & 16.8 & 22719 & 100.0 & 83.2 & 27291 & 100.0 \\
\hline
\end{tabular}


El Cuadro 2 nos revela que en los resguardos existe una proporción relativamente importante de personas (presentes y ausentes) que realizaron trabajos independientes o cuenta propia distintos a los de la finca: en Jambaló es el 18,4\%, en Toribío el 16,8\% y en Caldono el $14,3 \%$. Por sexo no se observan diferencias importantes, aunque los hombres son los que participan más en este tipo de trabajos.

Por otro lado, el porcentaje de personas que en los doce meses anteriores a la encuesta realizaron trabajos independientes o por cuenta propia distintos al de la finca por fuera del resguardo es del 15,9\% en Jambaló, del 6,3\% en Caldono y del 5,9\% en Toribío. Para esta población presentamos la información de los Gráficos 5 y 6 sobre el lugar de destino según sexo.

Gráfico 5. Lugares donde las personas de los cinco resguardos de Toribío, Jambaló y Caldono dedicaron tiempo al trabajo asalariado, Encuesta Piloto Experimental Nasa

Otros Mpios de Colombia

Cali y otros Mpios del Norte de Cauca y Sur del Valle

Otros Mpios Cauca

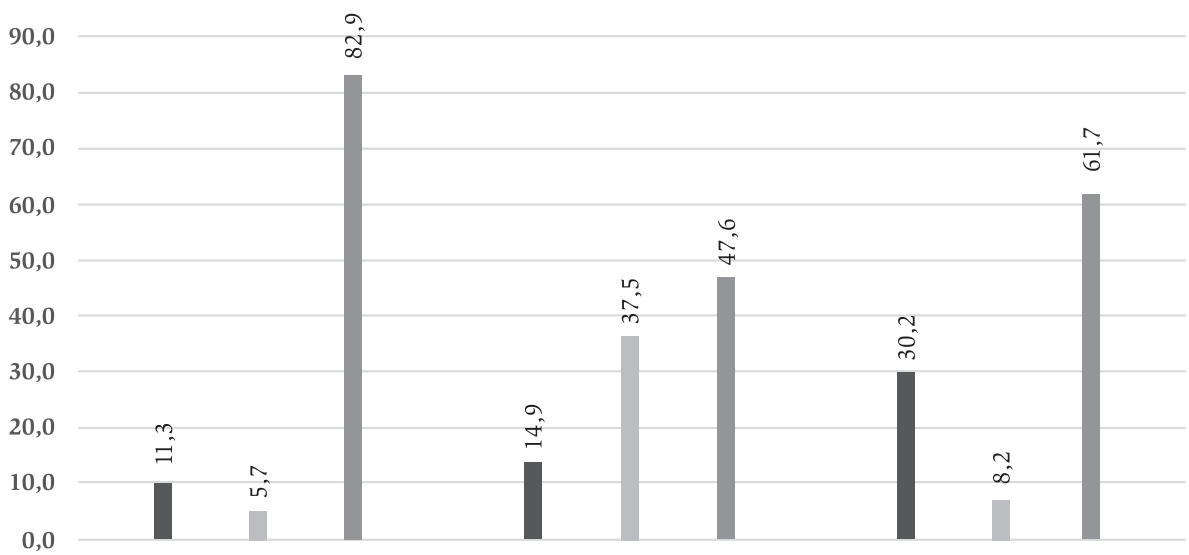


Gráfico 6. Lugares donde las personas de los cinco resguardos de Toribío, Jambaló y Caldono dedicaron tiempo al trabajo como independientes, Encuesta Piloto Experimental Nasa

Otros Mpios de Colombia

Cali y otros Mpios del Norte de Cauca y Sur del Valle

Otros Mpios Cauca

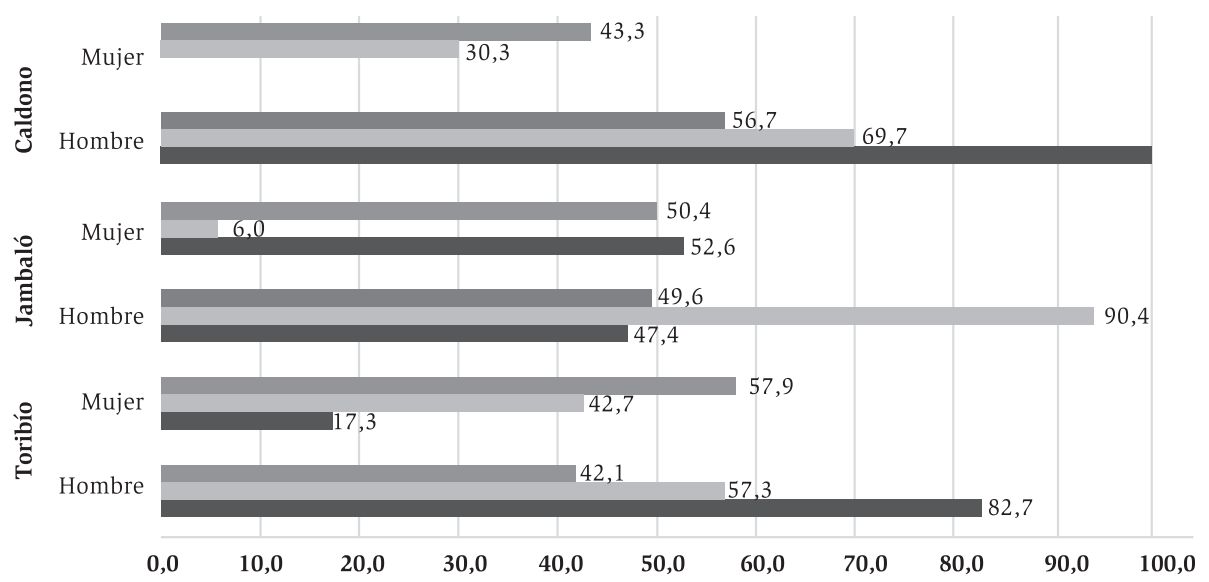

Según el Gráfico 5, Cali y los municipios de la región norte del Cauca y sur del Valle son el destino principal de las y los trabajadores independientes por fuera del resguardo: $82,9 \%$ en Toribío, $61,7 \%$ en Caldono y 47,6\% en Jambaló. Como veíamos previamente, este fenómeno también se presentó en el caso de las personas que se insertan en trabajos asalariados en otras fincas, hogares, fábricas y negocios. De nuevo, Toribío presenta el mayor grado de articulación al mercado laboral de Cali y la región, en este caso en actividades independientes o cuenta propia distintas a las de la finca (por ejemplo como pequeños comerciantes y artesanos).

Por sexo, tenemos que las mujeres de todos los resguardos de Toribío y Caldono que realizan trabajos independientes o por cuenta propia tienen como destino principal a la ciudad de Cali y los municipios de la región norte del Cauca y sur del Valle. Contrariamente, las mujeres de Jambaló 
tienen como destino predilecto de migración otros municipios de Colombia. En el caso de los hombres, otros municipios de Colombia son el epicentro de la migración de trabajadores independientes de Toribío y Caldono, y no la subregión norte del Cauca y sur del Valle, mientras que en Jambaló tienen más relevancia otros municipios del Cauca y Colombia, sin desconocer el peso que tienen Cali y las subregiones.

\section{Economía campesina indígena: acceso a tierra, ta- maño de los predios, cultivos y fuerza de trabajo}

\subsection{Acceso a tierra y tamaño de los predios}

La distribución del acceso a la tierra en los resguardos evidencia que en Toribío este es mucho menor en relación con los otros municipios, ya que el $15,6 \%$ de las UDPN no tiene acceso a la tierra. En contraste, en el resguardo de Jambaló menos del 3\% de los hogares no tiene acceso, mientras que Caldono se encuentra en una situación intermedia, con un 6,8\% de hogares sin acceso. La omisión de la cabecera en la aplicación de la encuesta en Jambaló, y su inclusión en Toribío y Caldono, influye un poco en los altos porcentajes de unidades domésticas sin acceso a tierra, aunque, como ya señalamos, las cabeceras municipales no tienen mucha importancia en términos demográficos en estos municipios.

El número promedio de los predios ayuda a entender la presión que ejerce la población sobre el territorio; en tal sentido, en los resguardos de Toribío y San Lorenzo de Caldono una UDPN tiene en promedio 1,4 predios, mientras que en Jambaló cada unidad de producción posee 1,9 predios en promedio (ver Anexo V).

El acceso a la tierra tiene una serie de implicaciones muy profundas en la sociedad indígena Nasa. En primera instancia, el número de predios configura la posibilidad de trabajar la tierra como actividad principal; en ese sentido, Jambaló tiene la mayor desviación estándar en relación 
con el número de predios en comparación con Caldono y Toribío $(4,1$ y 2,4 predios respectivamente). Lo anterior implica que, además del acceso mayoritario a tierra que tienen las UDPN de Jambaló, existe mayor variación en el número de predios que poseen estos hogares (ver Anexo V). El tamaño promedio de los predios es más alto en Jambaló (4,07 plazas $\left.^{10}\right)$ y le sigue Toribío (3,43 plazas); en cambio, el resguardo de San Lorenzo de Caldono tiene el tamaño promedio de predios más reducido de los resguardos (2,86 plazas).

Gráfico 7.\%Unidades domésticas sin acceso a tierra en los tres municipios de predominio indígena. Encuesta Piloto Experimental Nasa 2014-2015

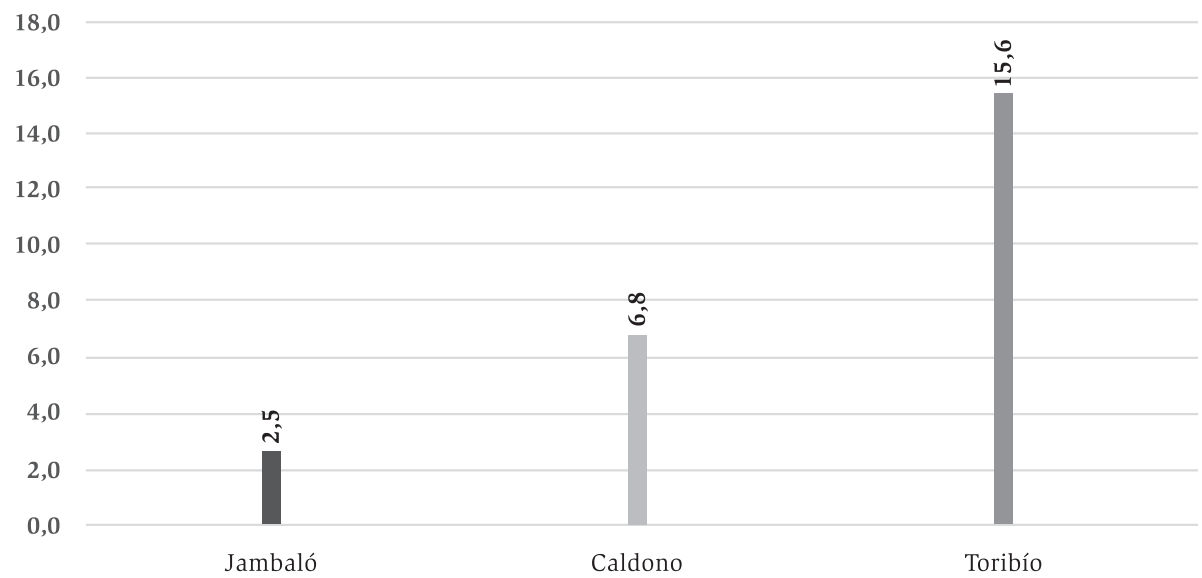

Para profundizar en el análisis del acceso a tierra, se transformó el área de los predios de metros a plazas para examinar la extensión promedio de los mismos, de esta forma encontramos que más de la tercera parte de las UDPN produce en menos de una plaza (46\%). Teniendo en cuenta lo anterior, a pesar de que en el municipio de Toribío el tamaño promedio del predio es más alto que en Caldono, el fenómeno del

$10 \quad$ Una plaza corresponde a 6.400 metros $^{2}$. 
microfundio es mucho más fuerte en los resguardos de este municipio debido al alto porcentaje de UDPN que producen en menos de una plaza $(45,8 \%)$. Para el caso del resguardo de Jambaló, la proporción de hogares que producen en un área menor a una plaza llega al 35,9\%, y en San Lorenzo de Caldono al 27,9\% (ver Gráfico 8).

Asimismo, a medida que aumenta el tamaño de los predios en plazas se observa que Caldono tiene las proporciones más altas de UDPN que producen en predios de entre 1,5 y 2 plazas (31,9\%), así como en predios de entre 3 y hasta 5 plazas $(22,9 \%)$. Igualmente, en Jambaló hay un porcentaje relativamente importante de unidades domésticas con acceso a predios de tamaños mayores a 10 plazas, frente a Toribío y Caldono $(5,7 \%, 4,5 \%$ y $2,6 \%$ respectivamente).

\section{Gráfico 8. Tamaño de los predios en plazas, Encuesta Piloto Experimental} Nasa 2014 - 2015*
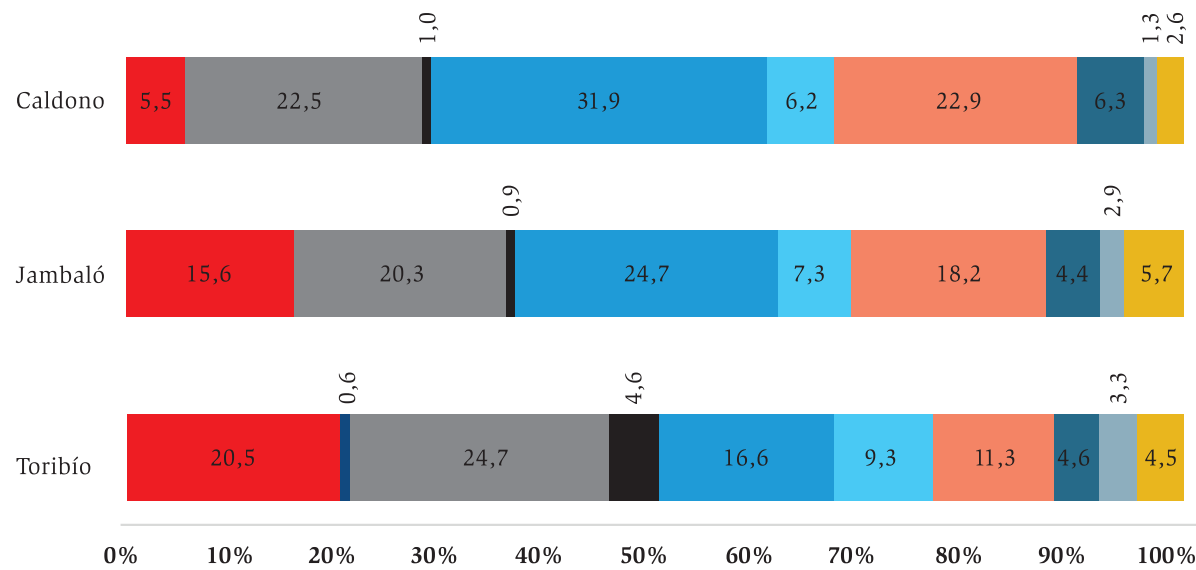

*Una plaza corresponde a 6400 metros cuadrados

Hasta media plaza

Más de $3 / 4$ hasta 1 plaza
De 1.1 a 1 $1 / 2$ plazas

De más de plaza y media hasta 2 plazas
De más de 2 plazas hasta 3 plazas

De más de 3 plazas hasta 5 plazas
De más de 5 plazas hasta 7 plazas

De más de 7 plazas hasta 10 plazas
Más de 10 plazas

De media plaza hasta $3 / 4$ de plazas 


\subsection{Cultivos y fuerza de trabajo}

En este apartado profundizamos en el análisis de la economía campesina Nasa. Para cumplir este objetivo se presentan los resultados sobre los cultivos principales y complementarios en los predios, el destino principal -venta o autoconsumo- de los mismos, el tipo de semilla y abono que utilizan las UDPN en los resguardos de San Lorenzo de Caldono, Jambaló y los tres resguardos del municipio de Toribío (Tacueyó, San Francisco y Toribío).

Por otro lado, retomando bajo ciertas condiciones la perspectiva de Chayanov, se analizan los indicadores relativos al porcentaje de fuerza de trabajo que utilizaron las unidades domésticas en el periodo de siembra y cosecha. Además, se presenta la proporción de hogares que pagaron jornal en estas fases del cultivo. Igualmente, se incluyen las horas promedio dedicadas al trabajo doméstico como cortar leña, cargar agua, cuidar a los niños, barrer y cocinar, por la incidencia que tienen sobre la reproducción de la fuerza de trabajo de las unidades domésticas.

Debido a factores socio-históricos y culturales, el cambio de mano y el trabajo comunitario cobran relevancia y resultan indispensables en la sociedad indígena-campesina Nasa. El cambio de mano es en efecto una práctica tradicional en los cinco resguardos de estos municipios; es más, en muchas de las actividades agropecuarias, el uso del cambio de mano es fundamental, principalmente en el periodo de cosecha. Por consiguiente, estimamos el promedio de veces y el porcentaje de personas que cambiaron de mano en el último año. El trabajo comunitario se refiere fundamentalmente al trabajo en la vereda o el resguardo en actividades como arreglar una carretera, construir o reparar infraestructura o en el "trabajo de ayuda" o solidario en otras fincas comunitarias o particulares (Vitonás, 2007).

En síntesis, esta sección nos permite comprender de mejor manera las prácticas ligadas a la actividad económica más importante y principal fuente de ingresos en esta zona de resguardos indígenas. 


\subsection{Cultivos principales y complementarios}

La economía campesina en esta región tiene un sustento importante en el autoconsumo para garantizar la reproducción de la fuerza de trabajo familiar; sin embargo, a diferencia de los postulados de Chayanov -en este sentido su enfoque analítico es insuficiente-, las UDPN tienen como fuente principal de ingresos los cultivos para la venta y, por lo mismo, dependen de las variaciones de los precios en el mercado global. Por esta razón se diferenció los cultivos entre principales y complementarios: el criterio que permite esta diferenciación radica en la extensión del área cultivada.

Gráfico 9. Destino de la producción según tipo de cultivo para los Resguardos de los tres municipios, Encuesta Piloto Experimental Nasa

Principal

Complementario

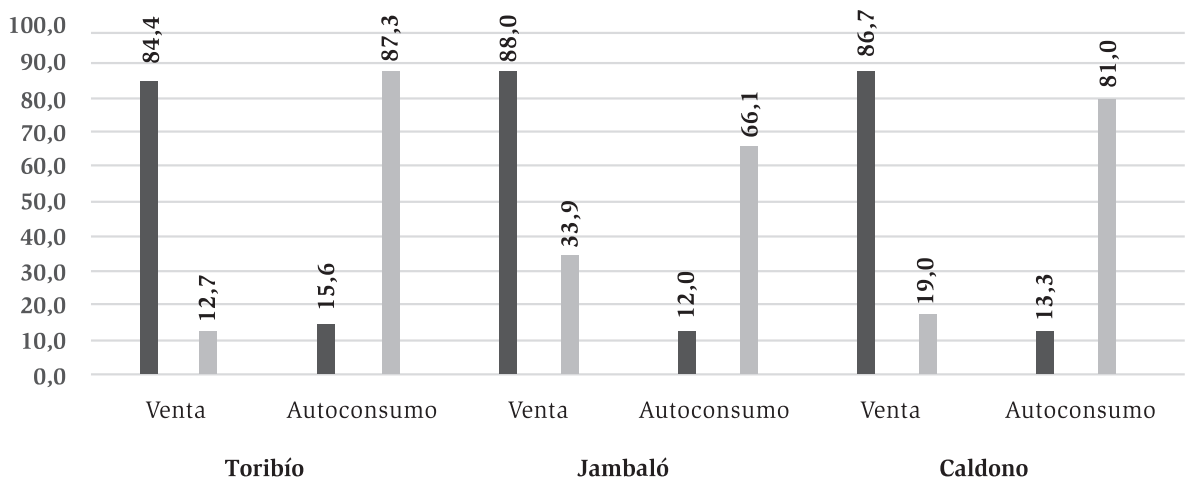

El Gráfico 9 muestra el destino de la producción según tipo de cultivo; es evidente que la gran mayoría de las unidades domésticas destina el cultivo principal para la venta y el complementario al autoconsumo. Según lo anterior, las unidades domésticas del resguardo de Jambaló 
y San Lorenzo de Caldono destinan una mayor proporción del cultivo principal a la venta ( $88 \%$ y $86,7 \%$ respectivamente) frente a las UDPN de los resguardos de Toribío $(84,4 \%)$. En relación con el cultivo complementario, se nota que en Toribío se destina la mayor parte para el autoconsumo, lo que implica que en los resguardos de Jambaló y Caldono los cultivos complementarios tienen una vinculación importante con el mercado que permite la generación de ingresos adicionales. En Toribío la reproducción de las unidades domésticas vía autoconsumo es más fuerte e importante que en los otros municipios, de ahí que incluso se destine el 15,6\% del cultivo principal para esta práctica.

La mayor proporción de cultivos principales corresponde a cultivos permanentes, mientras que los complementarios están asociados a una combinación entre los cultivos de ciclo corto y los permanentes (ver Anexo VI). El cultivo del café es el más importante en la economía campesina Nasa. De acuerdo con el Anexo VI, los hogares del resguardo de Jambaló destinan toda la producción de café para la venta; no obstante, en los resguardos de Toribío y Caldono existe una reducida fracción de UDPN que destinan una parte del café para el autoconsumo.

Otros cultivos principales importantes en esta zona son plátano, lulo, cebolla larga, granadilla, gulupa, tomate de árbol, naranja, yuca, papa y durazno, entre otros. Sin ser el objetivo de la encuesta, esta capturó los cultivos de coca y marihuana, los cuales fueron agrupados en una misma categoría. En ese sentido, cuando el cultivo de coca o marihuana es el principal, los hogares de Jambaló y Toribío destinan toda la cosecha a la venta, lo que demuestra que en estos territorios hay una mayor actividad de cultivos ilícitos con fines puramente económicos. Por el contrario, en el resguardo de San Lorenzo de Caldono no se capturó UDPN que tuviesen estos cultivos como principales. Los cultivos de ciclo corto tienen una participación no despreciable en la distribución de los cultivos principales, lo cual está ligado a mayores riesgos para los productores agrícolas (ver Anexo VI). 
Con respecto a los cultivos complementarios, la mayoría corresponde a cultivos de ciclo corto y a permanentes como plátano, tomate de árbol, cebolla larga, maíz, papa, yuca, arracacha, achira y los frutales como fresa, naranja, limón, mandarina, mora, guayaba, plátano, lulo, entre otros (ver Anexo VII). Estos cultivos son típicamente de pancoger, aunque algunos hogares de los cinco resguardos destinan la producción de éstos para la venta. Dentro de los complementarios, los cultivos de coca y marihuana tienen un mayor peso en los resguardos de Toribío en relación con los otros resguardos. En Caldono, curiosamente, los cultivos “ilícitos” se destinan principalmente para el autoconsumo, lo que evidencia el mantenimiento de prácticas culturales como mambear coca.

Ahora bien, la semilla natural es la más utilizada por las unidades domésticas en los cultivos de los cinco resguardos de estos municipios, pero frente a los otros resguardos, Toribío es donde se utiliza más este tipo de semilla (ver Gráfico 10). Análogamente, en el resguardo de Jambaló y de San Lorenzo de Caldono se utilizan en mayor medida las semillas certificadas. Según el tipo de cultivo, el Gráfico 12 revela que los cultivos complementarios se caracterizan por el uso intensivo de semillas naturales mientras que para los cultivos principales ocurre lo contrario. En ese sentido, las UDPN de los tres resguardos de Toribío emplean intensivamente la semilla certificada en los cultivos principales, incluso en una proporción ligeramente superior que los resguardos de Jambaló y de Caldono. El mayor uso de la semilla certificada en los cultivos principales está relacionado con las exigencias de la Federación Nacional de Cafeteros. 


\section{Gráfico 10. Tipo de semilla utilizada, Encuesta Piloto Experimental Nasa}

Principal

Complementario

Total

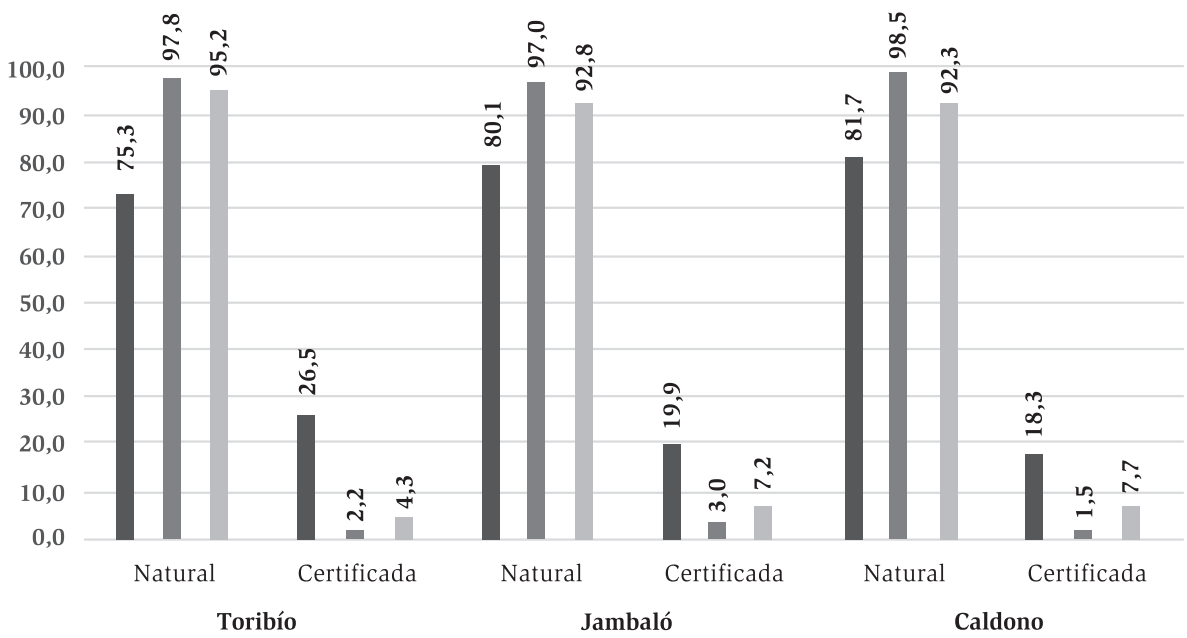

Del mismo modo, el Gráfico 11 nos da información sobre el tipo de abono que utilizan las UDPN en sus actividades agrícolas. Según los resultados, una importante proporción de hogares en Toribío $(67,8 \%)$ y en San Lorenzo de Caldono (55,8\%) usan abono orgánico en sus cultivos. El considerable uso de la semilla natural en los tres resguardos de Toribío se refleja en el menor porcentaje de utilización de abono químico en comparación con Jambaló y Caldono $(7,4 \%, 10 \%$ y 18,4\% respectivamente). Llama la atención que el $66 \%$ de las UDPN del resguardo de Jambaló no utilizan abonos en sus cultivos, mientras en los otros resguardos se observa un porcentaje similar de hogares que sí los utilizan. 


\section{Gráfico 11. Tipo de abano utilizado en los cultivos, Encuesta Piloto Experimental Nasa}

Toribío

Jambaló

Caldono

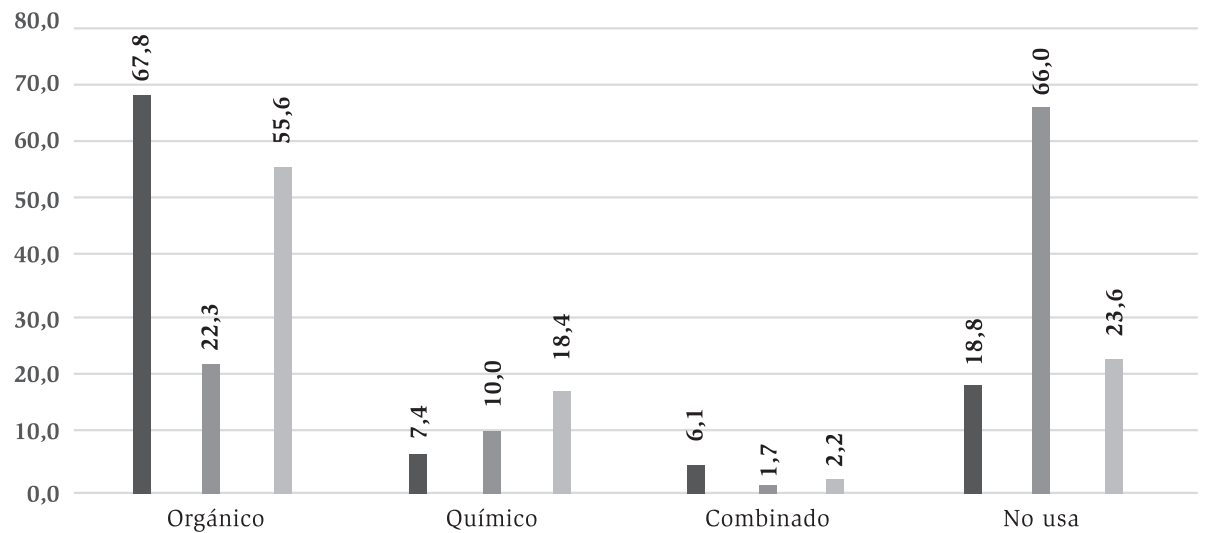

Otro hallazgo interesante está asociado con el tipo de abono usado según si son cultivos principales o complementarios. A este respecto, el Anexo VIII dilucida que la combinación de abono orgánico y químico es muy poco utilizada en los cultivos complementarios de los cinco resguardos. Por otro lado, esta combinación de abono es usada principalmente por las UDPN de San Lorenzo de Caldono y de los tres resguardos de Toribío en sus cultivos principales. En el caso de Jambaló, los hogares prefieren no utilizar abono en los cultivos principales.

En términos generales, la economía campesina Nasa tiene como cultivo principal el café y destinan los cultivos complementarios para el 
autoconsumo. Las prácticas agrícolas de los cinco resguardos indígenas no muestran diferencias en términos del tipo de semilla utilizada; sin embargo, cabe señalar que los datos revelan que las prácticas de cultivo relativamente más tradicionales se realizan en el resguardo de Jambaló, puesto que un porcentaje considerable de UDPN prescinde del uso de abono químico.

\subsection{Fuerza de trabajo familiar y producción agropecuaria}

Según Chayanov, la familia representa el motor de la actividad económica campesina (Kerblay, 1981). Lo anterior implica que en la dinámica de la economía campesina indígena hay una intensificación del trabajo familiar, lo que se traduce en más tiempo de trabajo doméstico, prolongación de las jornadas de trabajo e incremento del esfuerzo realizado en las actividades agropecuarias con la finalidad de suplir las necesidades de la unidad doméstica familiar (ver Anexo IX). En ese sentido, la autoexplotación o intensificación de la fuerza de trabajo familiar es la base de las actividades económicas en los resguardos indígenas de Toribío, Jambaló y Caldono.

Para demostrar el peso que tienen las actividades domésticas en la economía campesina indígena Nasa, se procedió a estimar el tiempo promedio que las personas destinaron a labores como barrer, trapear, lavar, cortar leña, cocinar, cargar agua, cuidar a los niños, a los animales o al Tul y el tiempo designado a tejer. El Anexo IX presenta información sobre el promedio de horas que las personas de cinco y más años de edad destinaron a estas tareas en la semana anterior a la encuesta. En este sentido, en Jambaló y en Toribío las personas dedicaron en promedio más horas al trabajo doméstico (27,3 y 26,9 horas respectivamente), mientras que en Caldono destinaron menos horas (22 horas). 
Siguiendo con los resultados anteriores, es evidente que las mujeres de todos los resguardos dedican más horas en promedio a las actividades domésticas que los hombres, pero son las de Toribío las que designan a estas labores más horas en promedio. En el caso de los hombres, los del resguardo de Jambaló dedicaron más horas en promedio que los de los otros resguardos.

Con respecto al número promedio de semanas que las personas de cinco y más años de edad destinaron al trabajo en la finca - en los cultivos para la venta o el autoconsumo- en los últimos seis meses, observamos que entre Toribío y Jambaló no hay diferencias sustanciales, $\neg 14,5$ semanas aproximadamente, lo que corresponde a tres meses y medio (ver Anexo X). Sin embargo, la diferencia con las personas de Caldono representa casi un mes menos de trabajo en la finca durante este periodo.

Según sexo, es de esperar que los hombres dediquen más semanas de trabajo a las actividades agropecuarias que las mujeres (ver Anexo X).

Asimismo, el trabajo comunitario incide en la mejora sustancial de las condiciones generales para la producción. En este sentido, las Juntas de Acción Comunal y el trabajo del Cabildo en las veredas del resguardo tienen gran poder de convocatoria, ya que en los cinco resguardos hay un porcentaje importante de personas que dedicaron tiempo al trabajo comunitario convocado por estas instituciones (ver Anexo XI).

En términos del uso de fuerza de trabajo en el periodo de siembra, la encuesta revela que el 70,2\% de las UDPN del resguardo de Jambaló utilizaron únicamente trabajo familiar en estas actividades agrícolas (ver Gráfico 12). 
Gráfico 12. Proporción de uso y explotación del trabajo familiar y del jornalero agrícola en el periodo de siembra de cultivos, Encuesta Piloto Experimental Nasa

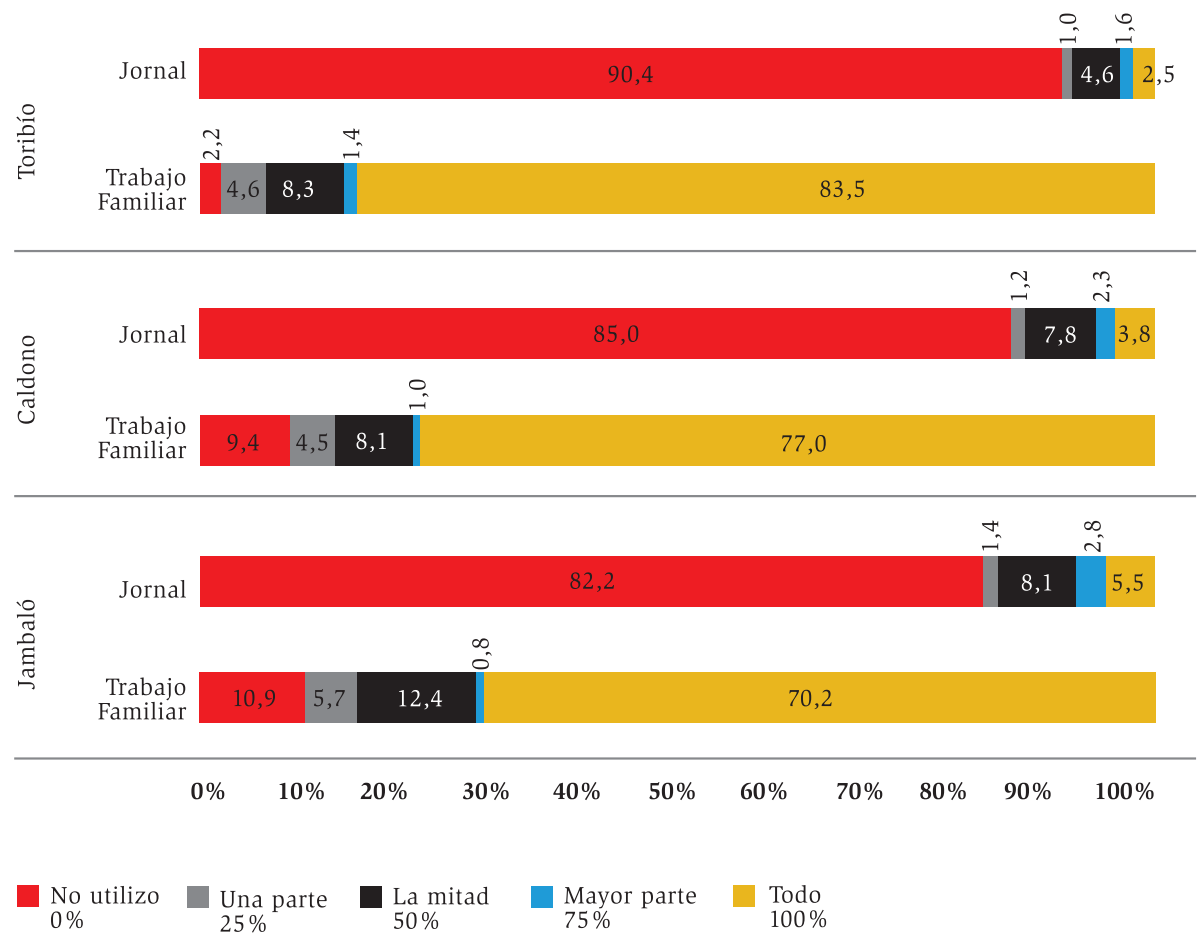

En San Lorenzo de Caldono, por su parte, el 77\% de los hogares utilizó trabajo familiar, mientras que en Toribío la proporción de hogares que utilizó esta fuera de trabajo es más alta en comparación con los otros resguardos: $83,5 \%$.

Existe una relación inversa entre la utilización del trabajo familiar y el pago del jornal; en otras palabras, las UDNP que usan intensamente 
trabajo familiar no pagan jornal y viceversa. De ahí que la mayor proporción de unidades domésticas que no pagaron jornal en el mismo periodo corresponde a las de los resguardos de Toribío (90,4\%), le siguen las UDPN de San Lorenzo de Caldono (85\%) y por último las de Jambaló $(82,2 \%)$. Esto corrobora que en Toribío el trabajo familiar en la finca pesa mucho más que en los otros municipios (ver Gráfico 12).

Durante el periodo de cosecha la tendencia es similar a la explicada anteriormente. Es decir, en los resguardos de Toribío se encuentra la proporción más alta de hogares que únicamente utilizaron fuerza de trabajo familiar en la cosecha $(90,9 \%)$, por encima de la mostrada por Caldono (73,8\%) y Jambaló (66,7\%) (ver Gráfico 13). Como era de esperar, el porcentaje más alto de hogares que no pagó jornal en el periodo de cosecha corresponde a los ubicados en Toribío $(95,7 \%)$, luego se ubican en importancia los hogares de Jambaló $(85,4 \%)$, mientras que en el resguardo de Caldono este porcentaje es más reducido $(78,2 \%)$ y se presenta la mayor participación de UDPN que pagaron jornaleros en cosecha $(5 \%)$.

El bajo porcentaje de hogares que pagan jornal en el periodo de siembra o cosecha está fuertemente relacionado con el uso de fuerza de trabajo en cambio de mano. A este respecto, el Gráfico 14 evidencia que el porcentaje de personas que realizó cambio de mano en los últimos doce meses es más alto en Jambaló (39\%) en comparación con los resguardos de Toribío $(23,4 \%)$ y Caldono $(16,6 \%)$. Por sexo, encontramos que la tendencia en los resguardos de Toribío y en San Lorenzo de Caldono es que los hombres tienen un porcentaje más alto con respecto al cambio de mano frente a las mujeres, lo cual no ocurre en Jambaló. 
Gráfico 13. Porcentajes de uso y explotación del trabajo familiar y del jornalero agrícola en el periodo de cosecha, Encuesta Piloto Experimental Nasa
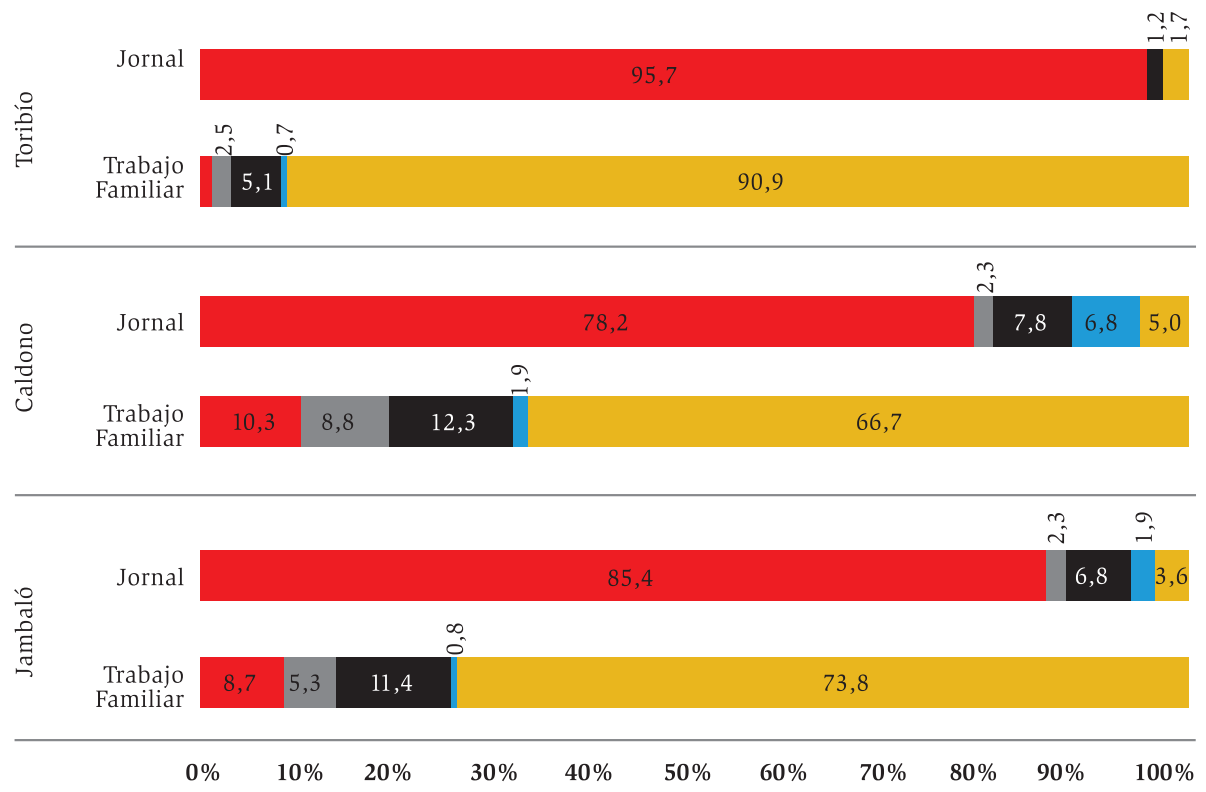

No utilizo $0 \%$

Sin embargo, a pesar de que las personas de los resguardos de Toribío presentan un menor porcentaje de participación en cambio de mano frente a Jambaló, el número de veces que cambió de mano es más alto en el primer municipio (ver Gráfico 15). Según sexo, encontramos un promedio de veces que se realizó cambio de mano mayor para los hombres, aunque con valores muy cercanos en el caso de las mujeres. 
Gráfico 14. Distribución porcentual de las personas de 10 y más años de edad que en el último año realizaron cambio de mano según sexo, Encuesta Piloto Experimental Nasa 2014-2015

Hombre $\quad$ Mujer Total

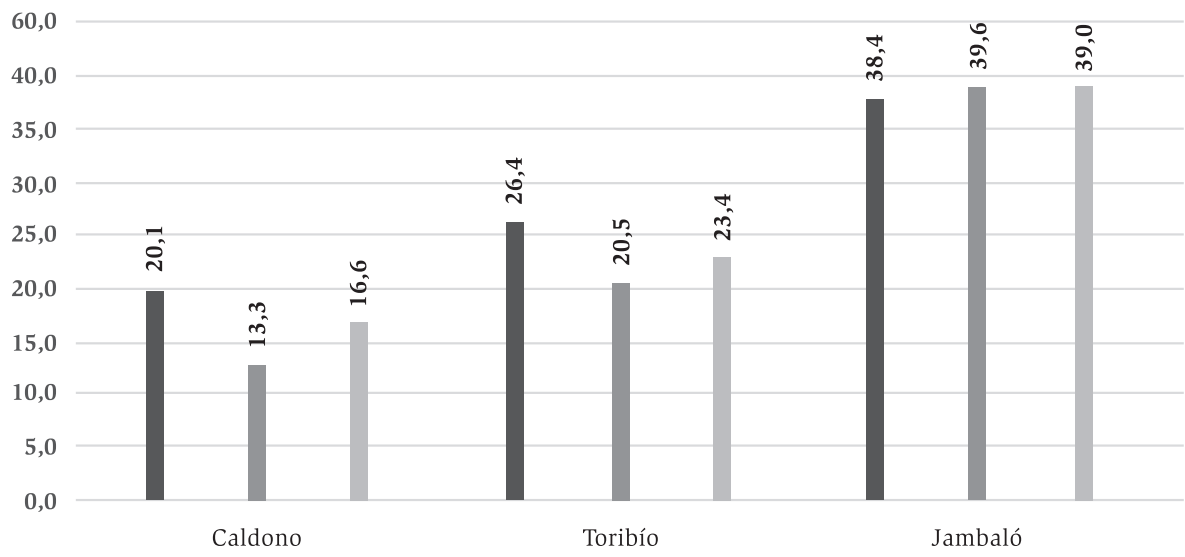

Gráfico 15. Promedio de veces en las que cambió de mano en el último año, Encuesta Piloto Experimental Nasa 2014-2015

Hombre Mujer Total

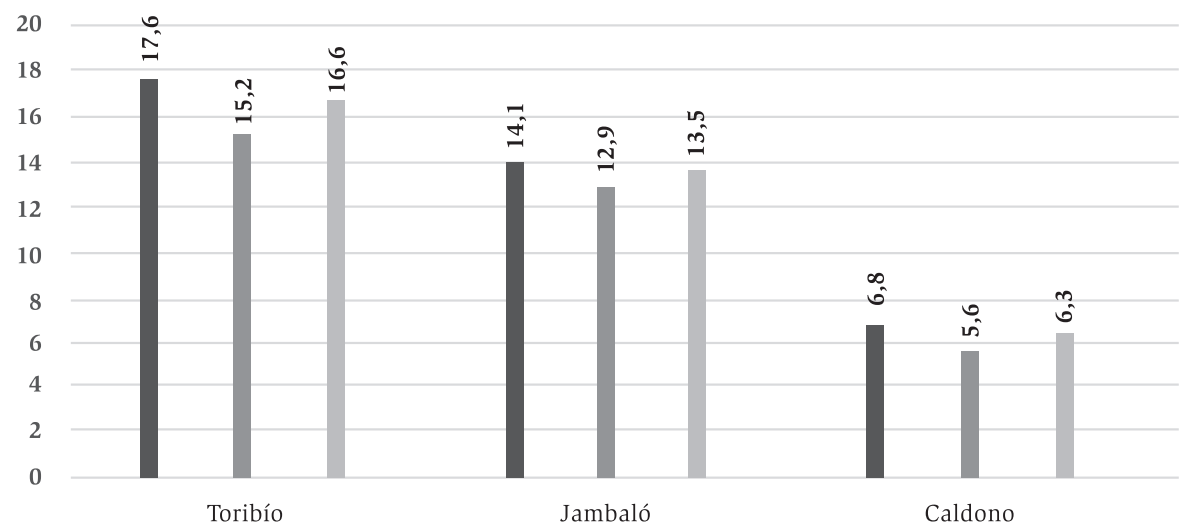




\section{Conclusiones}

Los tres municipios indígenas han consolidado economías campesinas con soporte de la institucionalidad Nasa a través de la organización indígena, especialmente en las últimas dos décadas. La autoridad indígena en estos territorios ha adjudicado predios a las familias, lo cual ha incidido en mejorar los mecanismos de generación de ingresos, fomentar el desarrollo productivo y articular la economía campesina al mercado a través de la venta de productos agropecuarios.

Detrás de los logros de los cabildos indígenas, subyace el entramado de relaciones sociolaborales que configuran la estructura ocupacional. Inicialmente, y como era de esperar, los indicadores convencionales del mercado de trabajo aplicados a una economía campesina revelan diferencias sustanciales en comparación con las áreas metropolitanas, ciudades intermedias y zonas rurales de agricultura comercial: bajos niveles de participación laboral y ocupación, alta inactividad laboral y desempleo casi friccional. No obstante, a pesar de evidenciar este hecho estilizado entre los mercados de trabajo urbanos y rurales, los indicadores presentados no logran capturar de manera adecuada la estructura de actividades en una economía campesina debido al inherente sesgo urbano de estos indicadores.

Con todo, la posición socio-ocupacional demuestra que muchas de las personas de estos municipios se desempeñan como trabajadores por cuenta propia, jornaleros o peones de fincas, obreros de empresa privada o pública y empleadas/os del servicio doméstico. El sector económico más importante corresponde típicamente al agropecuario donde, como se advirtió anteriormente, gran parte de las ocupaciones están relacionadas con el precultivo, siembra, cultivo, recolección/ cosecha y otras actividades agropecuarias. Esto reafirma el carácter rural de estas economías. Asimismo, otras ramas de actividad como la venta y comercio, la administración pública, los servicios educativos y de salud tienen una participación importante de trabajadores. 
Aunque un buen porcentaje de hogares en estos municipios tienen tierra, existen diferencias muy profundas en el acceso, tamaño y número de predios disponibles. La distribución de la tierra evidencia en el caso de los resguardos de Toribío un restringido acceso y la escasez de tierra, además de reducidos tamaños de los predios. Estas restricciones han llevado a una mayor diversificación de las actividades económicas de las familias. Dicha diversificación de oficios no se debe a una profundización de la demanda de trabajo, sino a la importancia que tienen los oficios del hogar en un contexto de economía campesina. Es decir, la diversificación productiva referida en la nueva ruralidad se presenta en este territorio no como avances en materia de inclusión laboral o mejoramiento en la estructura de oportunidades, sino como un mecanismo de resistencia de la economía campesina ante la escasez de tierras.

Por consiguiente, haciendo uso de otros indicadores, se considera de manera diferente el papel del trabajo doméstico sobre las UDPN. Así pues, en estos municipios no es posible desconocer la importancia que tienen el trabajo familiar en la finca durante el periodo de siembra y cosecha, el trabajo comunitario convocado por el Cabildo o la Junta de Acción Comunal (JAC), las prácticas rurales tradicionales como el cambio de mano ni tampoco el trabajo doméstico, debido a que tienen una incidencia directa en la reproducción de la fuerza de trabajo y las prácticas productivas.

El cultivo del café y la fuerza de trabajo son los dos canales de articulación de Toribío, Jambaló y Caldono con la región ampliada sur del Valle y norte del Cauca. Además, debido a la vocación comercial del cultivo principal, se posibilita la integración con mercados nacionales e internacionales. Igualmente, se encuentra un peso muy importante de cultivos complementarios de pancoger para el autoconsumo y, en resguardos como Jambaló y Caldono, también para la venta. El principal tipo de semilla es natural/tradicional y el tipo de abono es sobre todo orgánico, lo cual muestra que se practica una agricultura ecológica según las nuevas tendencias del mercado internacional. 
Por otro lado, las personas ausentes y en general las personas que han salido en los últimos doce meses del resguardo como independientes o asalariados, han logrado una importante inserción en el mercado laboral de Cali y los municipios de la región norte del Cauca y sur del Valle. La migración laboral de las mujeres Nasa se realiza fundamentalmente a estos municipios y su actividad principal es el empleo doméstico y en menor medida actividades de comercio y artesanales por cuenta propia. Los hombres de los resguardos que trabajan por fuera de su territorio también tienen como destino principal la ciudad de Cali y otros municipios del norte del Cauca y sur del Valle, principalmente como jornaleros o peones.

\section{Referencias}

Castaño, J.A. (2016). La presión demográfica sobre la tierra en Toribío, Cauca (Colombia) Rev. Colombiana de Sociología, 39(2), 263-280.

Kerblay, B. (1981). A.V. Chayanov: su vida, carrera y trabajos En: Chayanov y la Teoría de la Economía Campesina. Cuadernos de Pasado y Presente. México: Impreso por Siglo XXI, 1981.

Leibovich, J., Nigrinis, M., y Ramos, M. (2006). Caracterización del mercado laboral rural en Colombia. Borradores de Economía, 408.

Ocampo, J.A. (2015). El campo colombiano: un camino hacia el bienestar y la paz. Misión para la transformación del campo. Informe detallado de la Misión para la Transformación del Campo, Tomo I. Departamento Nacional de Planeación.

Shanin, T. (1976). Naturaleza y lógica de la economía campesina. Barcelona: Editorial Anagrama.

Vitonás, E. (2007). Formas de producción y distribución de la economía nasa. Etnias y Política. Volumen (9), 140-153. 


\section{Fuentes primarias}

Asociación de Cabildos Indígenas de Toribío, San Francisco y Tacueyó, "Proyecto Nasa", "Proyecto Global” y Cabildo de San Lorenzo de Caldono (2014/2015). Base de datos de la Encuesta Piloto Experimental Indígena Nasa sobre el Buen Vivir en Toribío, Tacueyó, San Francisco, Jambaló y San Lorenzo de Caldono. Fecha de consulta: agosto del 2016.

Departamento Administrativo Nacional de Estadística (DANE). (2014). Gran Encuesta Integrada de Hogares. Procesamientos especiales CIDSE con el micro-dato. 


\section{Anexos}

Anexo I. Distribución porcentual de las actividades a las que se ocupaban la semana pasada de los tres municipios de predominio Nasa en el norte del Cauca, Encuesta Piloto Experimental Nasa, 2014-2015

\begin{tabular}{|c|c|c|c|c|c|c|c|c|c|}
\hline $\begin{array}{l}\text { Actividad } \\
\text { semana }\end{array}$ & & Toribi & & & ambaló & & & Caldono & \\
\hline & Hombre & Mujer & Total & Hombre & Mujer & Total & Hombre & Mujer & Total \\
\hline Trabajando & 76.2 & 47.9 & 62.1 & 73.1 & 50.9 & 62.2 & 67.3 & 39.2 & 52.9 \\
\hline $\begin{array}{l}\text { Buscando } \\
\text { trabajo }\end{array}$ & 0.6 & 0.8 & 0.7 & 1.2 & 0.0 & 0.6 & 1.9 & 0.6 & 1.3 \\
\hline Estudiando & 17.6 & & 19.3 & 21.5 & 20.4 & 20.9 & 24.6 & 24.0 & 24.3 \\
\hline $\begin{array}{l}\text { Oficios del } \\
\text { Hogar }\end{array}$ & 3.4 & 27.8 & 15.6 & 1.2 & 25.8 & 13.3 & 2.7 & 34.8 & 19.2 \\
\hline $\begin{array}{l}\text { Incapacitado } \\
\text { permanente } \\
\text { para trabajar }\end{array}$ & 1.2 & 1.9 & 1.6 & 2.1 & 1.7 & 1.9 & 1.8 & 0.8 & 1.3 \\
\hline Otro & 0.9 & 0.7 & 0.8 & 1.0 & 1.2 & 1.1 & 1.7 & 0.6 & 1.1 \\
\hline Total & 100.0 & 100.0 & 100.0 & 100.0 & 100.0 & 100.0 & 100.0 & 100.0 & 100.0 \\
\hline
\end{tabular}

Anexo II. Distribución porcentual por tipo de ocupación de la población indígena que participa en el mercado de trabajo como ocupada, según sexo, en los tres municipios de predominio Nasa en el norte del Cauca, Encuesta Piloto Experimental Nasa, 2014-2015

\begin{tabular}{|lllllllllll|}
\hline Ocupación & \multicolumn{3}{c}{ Toribio } & \multicolumn{3}{c}{ Jambaló } & \multicolumn{3}{c|}{ Caldono } \\
\hline & Hombre & Mujer & Total & Hombre & Mujer & Total & Hombre & Mujer & Total \\
\hline Precultivo & 36.2 & 33.8 & 35.2 & 1.4 & 1.2 & 1.3 & 7.0 & 5.1 & 6.3 \\
\hline Siembra & 7.1 & 6.3 & 6.8 & 9.5 & 10.0 & 9.7 & 9.7 & 10.3 & 9.9 \\
\hline Cultivo & 11.2 & 9.3 & 10.4 & 7.1 & 6.2 & 6.7 & 2.8 & 3.2 & 2.9 \\
\hline $\begin{array}{l}\text { Recolección / } \\
\text { cosecha }\end{array}$ & 5.1 & 5.6 & 5.3 & 11.1 & 12.3 & 11.7 & 12.8 & 8.2 & 10.9 \\
\hline $\begin{array}{l}\text { Post cosecha } \\
\text { Otros actividades }\end{array}$ & 0.3 & 0.9 & 0.4 & 48.7 & 47.6 & 48.4 & 35.2 & 27.1 & 32.0 \\
\hline agropecuarias & 11.9 & 8.1 & 10.4 & 1.6 & 0.6 & 1.1 & 3.2 & 1.1 & 2.5 \\
\hline $\begin{array}{l}\text { Artesanos } \\
\text { Minería }\end{array}$ & 0.3 & 0.6 & 0.5 & 0.2 & 0.3 & 0.2 & 0.0 & 0.0 & 0.0 \\
\hline
\end{tabular}




\begin{tabular}{|c|c|c|c|c|c|c|c|c|c|}
\hline \multirow[t]{2}{*}{ Ocupación } & \multicolumn{3}{|c|}{ Toribio } & \multicolumn{3}{|c|}{ Jambaló } & \multicolumn{3}{|c|}{ Caldono } \\
\hline & Hombre & Mujer & Total & Hombre & Mujer & Total & Hombre & Mujer & Total \\
\hline Forestal & 0.0 & 0.0 & 0.0 & 1.8 & 0.5 & 1.2 & 2.5 & 1.0 & 1.8 \\
\hline $\begin{array}{l}\text { Trabajadores } \\
\text { comunitarios }\end{array}$ & 0.9 & 0.2 & 0.5 & 2.5 & 2.3 & 2.4 & 1.5 & 0.9 & 1.3 \\
\hline $\begin{array}{l}\text { Trabajadores no } \\
\text { calificados de } \\
\text { servicios (excepto } \\
\text { el personal } \\
\text { doméstico y } \\
\text { afines) }\end{array}$ & 3.5 & 1.7 & 2.7 & 2.5 & 0.6 & 1.7 & 3.0 & 0.5 & 2.0 \\
\hline $\begin{array}{l}\text { Oficiales, operarios } \\
\text { y trabajadores } \\
\text { de la industria } \\
\text { manufacturera, } \\
\text { construcción y } \\
\text { minería }\end{array}$ & 3.3 & 0.1 & 2.0 & 0.9 & 0.7 & 0.8 & 2.4 & 0.0 & 1.4 \\
\hline $\begin{array}{l}\text { Mecánicos y } \\
\text { ajustadores de } \\
\text { máquinas y } \\
\text { equipos }\end{array}$ & 0.1 & 0.0 & 0.2 & 0.5 & 0.0 & 0.3 & 1.0 & 0.0 & 0.5 \\
\hline $\begin{array}{l}\text { Trabajadores } \\
\text { de los servicios } \\
\text { personales }\end{array}$ & 2.4 & 4.7 & 3.2 & 0.3 & 2.2 & 1.0 & 0.5 & 11.1 & 4.6 \\
\hline Venta y comercio & 3.9 & 13.3 & 7.6 & 1.9 & 4.7 & 3.1 & 3.1 & 12.4 & 6.7 \\
\hline $\begin{array}{l}\text { Oficiales y } \\
\text { operarios de la } \\
\text { construcción }\end{array}$ & 1.4 & 0.1 & 0.9 & 5.0 & 1.9 & 3.7 & 9.7 & 2.5 & 6.8 \\
\hline $\begin{array}{l}\text { Operarios de } \\
\text { alimentos, textiles, } \\
\text { pieles, maderas y } \\
\text { afines }\end{array}$ & 1.1 & 3.2 & 1.9 & 0.0 & 1.7 & 0.7 & 0.0 & 3.7 & 1.6 \\
\hline Oficinistas & 1.9 & 0.2 & 1.3 & 0.2 & 0.5 & 0.3 & 0.0 & 0.6 & 0.2 \\
\hline Profesionales & 0.4 & 0.0 & 0.3 & 3.5 & 1.2 & 2.5 & 4.5 & 1.1 & 3.2 \\
\hline $\begin{array}{l}\text { Personal } \\
\text { doméstico, } \\
\text { aseadores, } \\
\text { lavanderos, } \\
\text { planchadores y } \\
\text { afines }\end{array}$ & 5.0 & 10.0 & 7.0 & 1.0 & 5.4 & 2.8 & 1.0 & 11.4 & 5.1 \\
\hline $\begin{array}{l}\text { Personal de los } \\
\text { servicios de } \\
\text { protección y } \\
\text { seguridad }\end{array}$ & 0.8 & 0.2 & 0.6 & 0.5 & 0.2 & 0.4 & 0.3 & 0.0 & 0.3 \\
\hline Admin. Pública & 0.1 & 0.1 & 0.2 & 0.0 & 0.0 & 0.0 & 0.0 & 0.0 & 0.0 \\
\hline $\begin{array}{l}\text { Otros técnicos, } \\
\text { postsecundarios } \\
\text { no universitarios y } \\
\text { asistentes }\end{array}$ & 1.8 & 1.4 & 1.7 & 0.0 & 0.0 & 0.0 & 0.0 & 0.0 & 0.0 \\
\hline Todo & 100.0 & 100.0 & 100.0 & 100.0 & 100.0 & 100.0 & 100.0 & 100.0 & 100.0 \\
\hline Observaciones & 10223 & 6880 & 17104 & 4774 & 3352 & 8126 & 3058 & 1976 & 5034 \\
\hline
\end{tabular}


Anexo III. Distribución porcentual por posición socio-ocupacional de la población indígena que participa en el mercado de trabajo como ocupada, según sexo, en los tres municipios de predominio Nasa en el norte del

Cauca, Encuesta Piloto Experimental Nasa, 2014-2015

\begin{tabular}{|c|c|c|c|c|c|c|c|c|c|}
\hline \multirow{3}{*}{$\begin{array}{l}\text { Posición } \\
\text { socio- } \\
\text { ocupacional }\end{array}$} & \multicolumn{9}{|c|}{ PRESENTE } \\
\hline & \multicolumn{3}{|c|}{ Toribio } & \multicolumn{3}{|c|}{ Jambaló } & \multicolumn{3}{|c|}{ Caldono } \\
\hline & Hombre & Mujer & Total & Hombre & Mujer & Total & Hombre & Mujer & Total \\
\hline $\begin{array}{l}\text { Trabajador } \\
\text { sin } \\
\text { remuneración }\end{array}$ & 12.4 & 24.7 & 17.3 & 14.1 & 33.5 & 22.1 & 2.3 & 5.6 & 3.6 \\
\hline $\begin{array}{l}\text { Trabajador } \\
\text { por cuenta } \\
\text { propia }\end{array}$ & 49.6 & 36.1 & 44.2 & 66.8 & 50.1 & 59.9 & 74.0 & 65.9 & 70.9 \\
\hline $\begin{array}{l}\text { Obrero(a) o } \\
\text { empleado(a) } \\
\text { del gobierno }\end{array}$ & 2.6 & 3.3 & 2.9 & 1.9 & 1.0 & 1.5 & 4.8 & 4.6 & 4.7 \\
\hline $\begin{array}{l}\text { Obrero(a) o } \\
\text { empleado(a) } \\
\text { del cabildo o } \\
\text { de empresa } \\
\text { comunitaria }\end{array}$ & 6.2 & 8.9 & 7.3 & 4.2 & 3.1 & 3.7 & 2.2 & 1.6 & 2.0 \\
\hline $\begin{array}{l}\text { Obrero(a) o } \\
\text { empleado(a) } \\
\text { de empresa } \\
\text { privada }\end{array}$ & 1.8 & 1.1 & 1.5 & 0.4 & 0.0 & 0.3 & 0.2 & 3.3 & 1.4 \\
\hline $\begin{array}{l}\text { Patrón o } \\
\text { empleador }\end{array}$ & 0.3 & 0.1 & 0.2 & 0.0 & 0.0 & 0.0 & 0.0 & 1.0 & 0.4 \\
\hline $\begin{array}{l}\text { Empleada(o) } \\
\text { doméstica(o) }\end{array}$ & 0.2 & 3.0 & 1.4 & 0.0 & 1.5 & 0.6 & 0.0 & 9.0 & 3.4 \\
\hline $\begin{array}{l}\text { Jornalero o } \\
\text { peón }\end{array}$ & 26.9 & 22.8 & 25.2 & 12.6 & 10.8 & 11.9 & 16.4 & 9.0 & 13.6 \\
\hline Total & 100.0 & 100.0 & 100.0 & 100.0 & 100.0 & 100.0 & 100.0 & 100.0 & 100.0 \\
\hline
\end{tabular}




\begin{tabular}{|c|c|c|c|c|c|c|c|c|c|}
\hline \multirow{3}{*}{$\begin{array}{l}\text { Posición } \\
\text { socio- } \\
\text { ocupacional }\end{array}$} & \multicolumn{9}{|c|}{ AUSENTE } \\
\hline & \multirow[b]{2}{*}{ Hombre } & \multicolumn{2}{|l|}{ Toribio } & \multicolumn{2}{|c|}{ Jambaló } & \multicolumn{4}{|c|}{ Caldono } \\
\hline & & Mujer & Total & Hombre & Mujer & Total & Hombre & Mujer & Total \\
\hline $\begin{array}{l}\text { Trabajador } \\
\text { sin } \\
\text { remuneración }\end{array}$ & 1.5 & 7.0 & 3.6 & 0.0 & 0.0 & 0.0 & 7.9 & 0.0 & 2.2 \\
\hline $\begin{array}{l}\text { Trabajador } \\
\text { por cuenta } \\
\text { propia }\end{array}$ & 14.5 & 14.7 & 14.6 & 8.6 & 31.5 & 16.8 & 8.5 & 1.6 & 3.4 \\
\hline $\begin{array}{l}\text { Obrero(a) o } \\
\text { empleado(a) } \\
\text { del gobierno }\end{array}$ & 11.5 & 2.8 & 8.2 & 5.7 & 0.0 & 3.6 & 0.0 & 0.0 & 0.0 \\
\hline $\begin{array}{l}\text { Obrero(a) o } \\
\text { empleado(a) } \\
\text { del cabildo o } \\
\text { de empresa } \\
\text { comunitaria }\end{array}$ & 0.0 & 0.0 & 0.0 & 0.0 & 0.0 & 0.0 & 21.8 & 2.8 & 7.9 \\
\hline $\begin{array}{l}\text { Obrero(a) o } \\
\text { empleado(a) } \\
\text { de empresa } \\
\text { privada }\end{array}$ & 22.0 & 2.4 & 14.6 & 14.5 & 20.8 & 16.8 & 0.0 & 0.0 & 0.0 \\
\hline $\begin{array}{l}\text { Patrón o } \\
\text { empleador }\end{array}$ & 0.0 & 2.4 & 0.9 & 0.0 & 0.0 & 0.0 & 0.0 & 0.0 & 0.0 \\
\hline $\begin{array}{l}\text { Empleada(o) } \\
\text { doméstica(o) }\end{array}$ & 0.0 & 55.6 & 21.1 & 0.0 & 33.7 & 12.1 & 0.0 & 82.4 & 60.0 \\
\hline $\begin{array}{l}\text { Jornalero o } \\
\text { peón }\end{array}$ & 50.4 & 15.0 & 37.0 & 71.3 & 13.9 & 50.6 & 61.9 & 13.3 & 26.5 \\
\hline Total & 100.0 & 100.0 & 100.0 & 100.0 & 100.0 & 100.0 & 100.0 & 100.0 & 100.0 \\
\hline
\end{tabular}




\section{Anexo IV. Distribución porcentual por ramas de actividad de la población indígena que participa en el mercado de trabajo como ocupada, según sexo, en los tres municipios de predominio Nasa en el norte del Cauca, Encuesta Piloto Experimental Nasa, 2014-2015}

\begin{tabular}{|c|c|c|c|c|c|c|c|c|c|}
\hline \multirow[t]{2}{*}{$\begin{array}{l}\text { Ramas de } \\
\text { actividad }\end{array}$} & \multicolumn{3}{|c|}{ Toribio } & \multicolumn{3}{|c|}{ Jambaló } & \multicolumn{3}{|c|}{ Caldono } \\
\hline & Hombre & Mujer & Total & Hombre & Mujer & Total & Hombre & Mujer & Total \\
\hline $\begin{array}{l}\text { Agricultura, } \\
\text { ganadería, caza, } \\
\text { pesca, acuicultura } \\
\text { y actividades de } \\
\text { servicios conexas } \\
\text { / explotacíón de } \\
\text { minas y canteras }\end{array}$ & 79.6 & 67.3 & 74.7 & 79.2 & 76.8 & 78.2 & 72.0 & 55.2 & 65.4 \\
\hline $\begin{array}{l}\text { Industrias } \\
\text { manufactureras } \\
\text { / Suministro de } \\
\text { electricidad, gas } \\
\text { y agua }\end{array}$ & 1.1 & 0.9 & 1.0 & 1.0 & 1.7 & 1.3 & 2.0 & 0.7 & 1.5 \\
\hline Construcción & 4.2 & 0.3 & 2.7 & 5.8 & 1.7 & 4.1 & 9.9 & 2.6 & 7.1 \\
\hline $\begin{array}{l}\text { Comercio, } \\
\text { reparación de } \\
\text { vehículos / Hoteles } \\
\text { y restaurantes }\end{array}$ & 4.8 & 14.0 & 8.5 & 2.1 & 5.4 & 3.5 & 4.1 & 16.1 & 8.8 \\
\hline $\begin{array}{l}\text { Transporte, } \\
\text { almacenamientos y } \\
\text { comunicaciones }\end{array}$ & 2.7 & 1.2 & 2.1 & 0.8 & 0.1 & 0.5 & 2.0 & 0.1 & 1.2 \\
\hline $\begin{array}{l}\text { Actividades } \\
\text { inmobiliarias, } \\
\text { de alquiler y } \\
\text { empresariales }\end{array}$ & 0.9 & 0.2 & 0.6 & 0.1 & 0.4 & 0.2 & 0.1 & 0.5 & 0.2 \\
\hline $\begin{array}{l}\text { Admin. pública, } \\
\text { educación, } \\
\text { servicios sociales } \\
\text { y salud }\end{array}$ & 4.1 & 8.5 & 5.9 & 10.2 & 8.8 & 9.6 & 8.7 & 12.3 & 10.1 \\
\hline $\begin{array}{l}\text { Otras actividades } \\
\text { de servicios } \\
\text { comunitarios, } \\
\text { sociales y } \\
\text { personales }\end{array}$ & 2.2 & 1.9 & 2.2 & 0.7 & 0.5 & 0.6 & 1.0 & 0.9 & 0.9 \\
\hline Empleo doméstico & 0.5 & 5.3 & 2.5 & 0.1 & 4.6 & 2.0 & 0.1 & 11.6 & 4.6 \\
\hline Total & 100.0 & 100.0 & 100.0 & 100.0 & 100.0 & 100.0 & 100.0 & 100.0 & 100.0 \\
\hline Observaciones & 10223 & 6880 & 17104 & 4774 & 3352 & 8126 & 3058 & 1976 & 5034 \\
\hline
\end{tabular}




\section{Anexo V. Distribución del número de predios para tres municipios de predominio indígena. Encuesta Piloto Experimental Nasa 2014-2015}

\begin{tabular}{|c|c|c|c|c|c|c|c|c|c|}
\hline \multirow[t]{2}{*}{ \#Predios } & \multicolumn{3}{|c|}{ Jambaló } & \multicolumn{3}{|c|}{ Caldono } & \multicolumn{3}{|c|}{ Toribio } \\
\hline & $\mathbf{N}$ & $\%$ Col & $\mathbf{N}$ & $\% \mathrm{Col}$ & $\mathbf{N}$ & $\% \mathrm{Col}$ & Hombre & Mujer & Total \\
\hline 1 & 1625 & 44.6 & 2182 & 75.6 & 4368 & 72.5 & 72.0 & 55.2 & 65.4 \\
\hline 2 & 1365 & 37.4 & 539 & 18.7 & 1255 & 20.8 & 2.0 & 0.7 & 1.5 \\
\hline 3 & 344 & 9.4 & 92 & 3.2 & 207 & 3.4 & 9.9 & 2.6 & 7.1 \\
\hline 4 & 181 & 5.0 & 38 & 1.3 & 120 & 2.0 & 4.1 & 16.1 & 8.8 \\
\hline 5 & 88 & 2.4 & 17 & 0.6 & 20 & 0.3 & 2.0 & 0.1 & 1.2 \\
\hline 6 & 9 & 0.3 & 17 & 0.6 & 16 & 0.3 & 0.1 & 0.5 & 0.2 \\
\hline 7 & 0 & 0.0 & 0 & 0.0 & 0 & 0.0 & 8.7 & 12.3 & 10.1 \\
\hline 8 & 34 & 0.9 & 0 & 0.0 & 41 & 0.7 & 1.0 & 0.9 & 0.9 \\
\hline Total & 3646 & 100.0 & 2885 & 100.0 & 6027 & 100.0 & 0.1 & 11.6 & 4.6 \\
\hline $\begin{array}{l}\text { Desviación } \\
\text { estándar }\end{array}$ & 4.07 & & 2.38 & & 2.45 & & 100.0 & 100.0 & 100.0 \\
\hline Promedio & 1.9 & & 1.4 & & 1.4 & & 3058 & 1976 & 5034 \\
\hline $\begin{array}{l}\text { Tamaño } \\
\text { promedio (en } \\
\text { plazas) }\end{array}$ & 4.07 & & 2.86 & & 3.43 & & & & \\
\hline
\end{tabular}




\section{Anexo VI. Distribución de los cultivos principales según destino de la pro- ducción, Encuesta Piloto Experimental Nasa}

\begin{tabular}{|c|c|c|c|c|c|c|c|c|}
\hline \multicolumn{9}{|c|}{ TORIBÍO } \\
\hline \multirow[t]{2}{*}{$\begin{array}{l}\text { Sólo Cultivos } \\
\text { principales }\end{array}$} & \multicolumn{3}{|c|}{ Venta } & \multicolumn{3}{|c|}{ Autoconsumo } & \multicolumn{2}{|c|}{ Total } \\
\hline & $\mathrm{N}$ & $\% \mathrm{Col}$ & $\%$ Fil & $\mathrm{N}$ & $\% \mathrm{Col}$ & $\%$ Fil & $\mathrm{N}$ & $\% \mathrm{Col}$ \\
\hline Café & 454 & 75.5 & 94.6 & 26 & 23.6 & 5.4 & 480 & 67.5 \\
\hline Plátano & 20 & 3.3 & 34.5 & 38 & 34.5 & 65.5 & 58 & 8.2 \\
\hline $\begin{array}{l}\text { Otros } \\
\text { permanentes }\end{array}$ & . & . & . & . & . & . & . & . \\
\hline $\begin{array}{l}\text { Toma Árbol/ } \\
\text { Lulo }\end{array}$ & 6 & 1.0 & 42.9 & 8 & 7.3 & 57.1 & 14 & 2.0 \\
\hline Mora & . & . & . & . & . & . & . & . \\
\hline Cebolla larga & 28 & 4.7 & 100.0 & . & . & . & 28 & 3.9 \\
\hline $\begin{array}{l}\text { Subtotal } \\
\text { cultivos } \\
\text { permanentes }\end{array}$ & 508 & 84.5 & 87.6 & 72 & 65.5 & 12.4 & 580 & 81.6 \\
\hline Maíz & . & . & . & 22 & 20.0 & 100.0 & 22 & 3.1 \\
\hline $\begin{array}{l}\text { Otros de ciclo } \\
\text { corto }\end{array}$ & 55 & 9.2 & 88.7 & 7 & 6.4 & 11.3 & 62 & 8.7 \\
\hline Рapa & 6 & 1.0 & 100.0 & . & . & . & 6 & 0.8 \\
\hline Yuca & . & . & . & 9 & 8.2 & 100.0 & 9 & 1.3 \\
\hline $\begin{array}{l}\text { Subtotal } \\
\text { cultivos de } \\
\text { ciclo corto }\end{array}$ & 61 & 10.1 & 61.6 & 38 & 34.5 & 38.4 & 99 & 13.9 \\
\hline $\begin{array}{l}\text { Coca/ } \\
\text { Marihuana }\end{array}$ & 32 & 5.3 & 100.0 & . & . & . & 32 & 4.5 \\
\hline $\begin{array}{l}\text { Subtotal } \\
\text { cultivos } \\
\text { culturales }\end{array}$ & 32 & 5.3 & 100.0 & . & . & . & 32 & 4.5 \\
\hline Total & 601 & 100.0 & 84.5 & 110 & 100.0 & 15.5 & 711 & 100.0 \\
\hline
\end{tabular}




\begin{tabular}{|c|c|c|c|c|c|c|c|c|}
\hline \multicolumn{9}{|c|}{ JAMBALÓ } \\
\hline \multirow[t]{2}{*}{$\begin{array}{l}\text { Sólo Cultivos } \\
\text { principales }\end{array}$} & \multicolumn{3}{|c|}{ Venta } & \multicolumn{3}{|c|}{ Autoconsumo } & \multicolumn{2}{|c|}{ Total } \\
\hline & $\mathrm{N}$ & $\% \mathrm{Col}$ & \% Fil & $\mathrm{N}$ & $\% \mathrm{Col}$ & $\%$ Fil & $\mathrm{N}$ & $\% \mathrm{Col}$ \\
\hline Café & 502 & 76.5 & 100.0 & . & . & . & 502 & 67.3 \\
\hline Plátano & . & . & . & 23 & 25.5 & 100.0 & 23 & 3.1 \\
\hline $\begin{array}{l}\text { Otros } \\
\text { permanentes }\end{array}$ & 98 & 15.0 & 92.3 & 8 & 9.2 & 7.7 & 107 & 14.3 \\
\hline $\begin{array}{l}\text { Toma Árbol/ } \\
\text { Lulo }\end{array}$ & . & . & . & . & . & . & . & . \\
\hline Mora & . & . & . & . & . & . & . & . \\
\hline Cebolla larga & . & . & . & 7 & 8.3 & 100.0 & 7 & 1.0 \\
\hline $\begin{array}{l}\text { Subtotal } \\
\text { cultivos } \\
\text { permanentes }\end{array}$ & 600 & 91.5 & 94.0 & 38 & 43.0 & 6.0 & 639 & 85.7 \\
\hline Maíz & . & . & . & 26 & 29.0 & 100.0 & 26 & 3.5 \\
\hline $\begin{array}{l}\text { Otros de ciclo } \\
\text { corto }\end{array}$ & 8 & 1.2 & 100.0 & . & . & . & 8 & 1.0 \\
\hline Papa & 32 & 4.9 & 100.0 & . & . & . & 32 & 4.4 \\
\hline Yuca & . & . & . & 25 & 28.0 & 100.0 & 25 & 3.3 \\
\hline $\begin{array}{l}\text { Subtotal } \\
\text { cultivos de } \\
\text { ciclo corto }\end{array}$ & 40 & 6.1 & 44.0 & 51 & 57.0 & 56.0 & 91 & 12.2 \\
\hline $\begin{array}{l}\text { Coca/ } \\
\text { Marihuana }\end{array}$ & 16 & 2.4 & 100.0 & . & . & . & 16 & 2.1 \\
\hline $\begin{array}{l}\text { Subtotal } \\
\text { cultivos } \\
\text { culturales }\end{array}$ & 16 & 2.4 & 100.0 & . & . & . & 16 & 2.1 \\
\hline Total & 656 & 100.0 & 88.0 & 89 & 100.0 & 12.0 & 745 & 100.0 \\
\hline
\end{tabular}




\begin{tabular}{|c|c|c|c|c|c|c|c|c|}
\hline \multicolumn{9}{|c|}{ CALDONO } \\
\hline \multirow[t]{2}{*}{$\begin{array}{l}\text { Sólo Cultivos } \\
\text { principales }\end{array}$} & \multicolumn{3}{|c|}{ Venta } & \multicolumn{3}{|c|}{ Autoconsumo } & \multicolumn{2}{|c|}{ Total } \\
\hline & $\mathrm{N}$ & $\% \mathrm{Col}$ & $\%$ Fil & $\mathrm{N}$ & $\% \mathrm{Col}$ & $\%$ Fil & $\mathrm{N}$ & $\% \mathrm{Col}$ \\
\hline Café & 584 & 76.4 & 96.8 & 19 & 16.4 & 3.2 & 603 & 68.5 \\
\hline Plátano & . & . & . & . & . & . & . & . \\
\hline $\begin{array}{l}\text { Otros } \\
\text { permanentes }\end{array}$ & 157 & 20.5 & 95.9 & 7 & 5.7 & 4.1 & 163 & 18.5 \\
\hline $\begin{array}{l}\text { Toma Árbol/ } \\
\text { Lulo }\end{array}$ & . & . & . & . & . & . & . & . \\
\hline Mora & 7 & 0.9 & 100.0 & . & . & . & 7 & 0.8 \\
\hline Cebolla larga & 0 & 0.0 & 0.0 & 46 & 39.7 & 100.0 & 46 & 5.3 \\
\hline $\begin{array}{l}\text { Subtotal } \\
\text { cultivos } \\
\text { permanentes }\end{array}$ & 748 & 97.8 & 91.2 & 72 & 61.8 & 8.8 & 820 & 93.1 \\
\hline Maíz & 7 & 0.9 & 55.8 & 6 & 4.8 & 44.2 & 13 & 1.4 \\
\hline $\begin{array}{l}\text { Otros de ciclo } \\
\text { corto }\end{array}$ & . & . & . & 4 & 3.4 & 100.0 & 4 & 0.5 \\
\hline Рара & . & . & . & . & . & . & . & . \\
\hline Yuca & 9 & 1.2 & 21.2 & 35 & 30.0 & 78.8 & 44 & 5.0 \\
\hline $\begin{array}{l}\text { Subtotal } \\
\text { cultivos de } \\
\text { ciclo corto }\end{array}$ & 17 & 2.2 & 27.0 & 45 & 38.2 & 73.0 & 61 & 6.9 \\
\hline $\begin{array}{l}\text { Coca/ } \\
\text { Marihuana }\end{array}$ & . & . & . & . & . & . & . & . \\
\hline $\begin{array}{l}\text { Subtotal } \\
\text { cultivos } \\
\text { culturales }\end{array}$ & . & . & . & . & . & . & . & . \\
\hline Total & 764 & 100.0 & 86.7 & 117 & 100.0 & 13.3 & 881 & 100.0 \\
\hline
\end{tabular}




\section{Anexo VII. Distribución de los cultivos principales según destino de la producción, Encuesta Piloto Experimental Nasa}

\begin{tabular}{|c|c|c|c|c|c|c|c|c|}
\hline \multicolumn{9}{|c|}{ TORIBÍO } \\
\hline \multirow[t]{2}{*}{$\begin{array}{l}\text { Cultivos } \\
\text { complementarios }\end{array}$} & \multicolumn{3}{|c|}{ Venta } & \multicolumn{3}{|c|}{ Autoconsumo } & \multicolumn{2}{|c|}{ Total } \\
\hline & $\mathrm{N}$ & $\% \mathrm{Col}$ & $\%$ fll & $\mathrm{N}$ & $\% \mathrm{Col}$ & $\%$ fll & $\mathrm{N}$ & $\% \mathrm{Col}$ \\
\hline Café & 61 & 8.1 & 71.8 & 24 & 0.5 & 28.2 & 85 & 1.4 \\
\hline Plátano & 54 & 7.2 & 9.2 & 534 & 10.3 & 90.8 & 588 & 9.9 \\
\hline $\begin{array}{l}\text { Otros } \\
\text { permanentes }\end{array}$ & 23 & 3.1 & 7.0 & 306 & 5.9 & 93.0 & 329 & 5.6 \\
\hline Toma Árbol/Lulo & 52 & 6.9 & 28.1 & 133 & 2.6 & 71.9 & 185 & 3.1 \\
\hline Fresa & 8 & 1.1 & 100.0 & . & . & . & 8 & 0.1 \\
\hline Guayaba & . & . & . & 113 & 2.2 & 100.0 & 113 & 1.9 \\
\hline Naranja & 25 & 3.3 & 10.0 & 226 & 4.4 & 90.0 & 251 & 4.2 \\
\hline Mandarina & . & . & . & 138 & 2.7 & 100.0 & 138 & 2.3 \\
\hline Limón & 7 & 0.9 & 2.4 & 289 & 5.6 & 97.6 & 296 & 5.0 \\
\hline Mora & 6 & 0.8 & 6.3 & 90 & 1.7 & 93.8 & 96 & 1.6 \\
\hline Cebolla larga & 30 & 4.0 & 19.6 & 123 & 2.4 & 80.4 & 153 & 2.6 \\
\hline $\begin{array}{l}\text { Subtotal cultivos } \\
\text { permanentes }\end{array}$ & 266 & 35.3 & 11.9 & 1976 & 38.2 & 88.1 & 2242 & 37.8 \\
\hline Maíz & 25 & 3.3 & 7.4 & 311 & 6.0 & 92.6 & 336 & 5.7 \\
\hline $\begin{array}{l}\text { Otros de ciclo } \\
\text { corto }\end{array}$ & 137 & 18.2 & 12.9 & 924 & 17.9 & 87.1 & 1061 & 17.9 \\
\hline Papa & 20 & 2.7 & 22.0 & 71 & 1.4 & 78.0 & 91 & 1.5 \\
\hline Yuca & 72 & 9.6 & 14.8 & 415 & 8.0 & 85.2 & 487 & 8.2 \\
\hline $\begin{array}{l}\text { Subtotal cultivos } \\
\text { de ciclo corto }\end{array}$ & 254 & 33.7 & 12.9 & 1721 & 33.3 & 87.1 & 1975 & 33.3 \\
\hline $\begin{array}{l}\text { Otros cultivos } \\
\text { culturales }\end{array}$ & 60 & 8.0 & 4.1 & 1406 & 27.2 & 95.9 & 1466 & 24.7 \\
\hline Coca/Marihuana & 173 & 23.0 & 71.8 & 68 & 1.3 & 28.2 & 241 & 4.1 \\
\hline $\begin{array}{l}\text { Subtotal cultivos } \\
\text { culturales }\end{array}$ & 233 & 30.9 & 13.6 & 1474 & 28.5 & 86.4 & 1707 & 28.8 \\
\hline Total & 753 & 100.0 & 12.7 & 5171 & 100.0 & 87.3 & 5924 & 100.0 \\
\hline
\end{tabular}




\begin{tabular}{|c|c|c|c|c|c|c|c|c|}
\hline \multicolumn{9}{|c|}{ JAMBALÓ } \\
\hline \multirow{2}{*}{$\begin{array}{l}\text { Cultivos } \\
\text { complementarios }\end{array}$} & \multicolumn{3}{|c|}{ Venta } & \multicolumn{3}{|c|}{ Autoconsumo } & \multicolumn{2}{|c|}{ Total } \\
\hline & $\mathrm{N}$ & $\% \mathrm{Col}$ & $\%$ fll & $\mathrm{N}$ & $\% \mathrm{Col}$ & $\%$ fll & $\mathrm{N}$ & $\% \mathrm{Col}$ \\
\hline Café & 117 & 15.0 & 87.8 & 16 & 1.1 & 12.2 & 133 & 5.8 \\
\hline Plátano & 125 & 16.1 & 22.8 & 424 & 28.0 & 77.2 & 550 & 24.0 \\
\hline $\begin{array}{l}\text { Otros } \\
\text { permanentes }\end{array}$ & 117 & 15.1 & 55.4 & 94 & 6.2 & 44.6 & 212 & 9.2 \\
\hline Toma Árbol/Lulo & 42 & 5.3 & 64.8 & 23 & 1.5 & 35.2 & 64 & 2.8 \\
\hline Fresa & . & . & . & . & . & . & . & . \\
\hline Guayaba & . & . & . & 13 & 0.9 & 100.0 & 13 & 0.6 \\
\hline Naranja & 44 & 5.7 & 51.3 & 42 & 2.8 & 48.7 & 86 & 3.8 \\
\hline Mandarina & 5 & 0.7 & 47.4 & 6 & 0.4 & 52.6 & 11 & 0.5 \\
\hline Limón & . & . & . & . & . & . & . & . \\
\hline Mora & . & . & . & . & . & . & . & . \\
\hline Cebolla larga & . & . & . & 14 & 0.9 & 100.0 & 14 & 0.6 \\
\hline $\begin{array}{l}\text { Subtotal cultivos } \\
\text { permanentes }\end{array}$ & 450 & 58.0 & 41.6 & 633 & 41.8 & 58.4 & 1083 & 47.3 \\
\hline Maíz & 70 & 9.1 & 30.8 & 158 & 10.5 & 69.2 & 229 & 10.0 \\
\hline $\begin{array}{l}\text { Otros de ciclo } \\
\text { corto }\end{array}$ & 106 & 13.6 & 29.7 & 250 & 16.5 & 70.3 & 356 & 15.5 \\
\hline Рара & 27 & 3.4 & 86.0 & 4 & 0.3 & 14.0 & 31 & 1.4 \\
\hline Yuca & 60 & 7.7 & 13.6 & 378 & 25.0 & 86.4 & 437 & 19.1 \\
\hline $\begin{array}{l}\text { Subtotal cultivos } \\
\text { de ciclo corto }\end{array}$ & 262 & 33.8 & 24.9 & 790 & 52.2 & 75.1 & 1053 & 46.0 \\
\hline $\begin{array}{l}\text { Otros cultivos } \\
\text { culturales }\end{array}$ & 54 & 7.0 & 37.6 & 90 & 6.0 & 62.4 & 144 & 6.3 \\
\hline Coca/Marihuana & 10 & 1.2 & 100.0 & . & . & . & 10 & 0.4 \\
\hline $\begin{array}{l}\text { Subtotal cultivos } \\
\text { culturales }\end{array}$ & 64 & 8.2 & 41.5 & 90 & 6.0 & 58.5 & 154 & 6.7 \\
\hline Total & 776 & 100.0 & 33.9 & 1513 & 100.0 & 66.1 & 2290 & 100.0 \\
\hline
\end{tabular}




\begin{tabular}{|c|c|c|c|c|c|c|c|c|}
\hline \multicolumn{9}{|c|}{ CALDONO } \\
\hline \multirow[t]{2}{*}{$\begin{array}{l}\text { Cultivos } \\
\text { complementarios }\end{array}$} & \multicolumn{3}{|c|}{ Venta } & \multicolumn{3}{|c|}{ Autoconsumo } & \multicolumn{2}{|c|}{ Total } \\
\hline & $\mathrm{N}$ & $\% \mathrm{Col}$ & $\%$ fll & $\mathrm{N}$ & $\% \mathrm{Col}$ & $\%$ fll & $\mathrm{N}$ & $\% \mathrm{Col}$ \\
\hline Café & 8 & 2.6 & 44.7 & 10 & 0.8 & 55.3 & 17 & 1.1 \\
\hline Plátano & 25 & 8.6 & 5.4 & 440 & 35.1 & 94.6 & 466 & 30.0 \\
\hline $\begin{array}{l}\text { Otros } \\
\text { permanentes }\end{array}$ & 146 & 49.3 & 42.2 & 199 & 15.9 & 57.8 & 345 & 22.3 \\
\hline Toma Árbol/Lulo & . & . & . & . & . & . & . & . \\
\hline Fresa & . & . & . & . & . & . & . & . \\
\hline Guayaba & . & . & . & 14 & 1.1 & 100.0 & 14 & 0.9 \\
\hline Naranja & . & . & . & 9 & 0.7 & 100.0 & 9 & 0.6 \\
\hline Mandarina & . & . & . & 10 & 0.8 & 100.0 & 10 & 0.6 \\
\hline Limón & . & . & . & 3 & 0.2 & 100.0 & 3 & 0.2 \\
\hline Mora & 43 & 14.7 & 90.6 & 5 & 0.4 & 9.4 & 48 & 3.1 \\
\hline Cebolla larga & . & . & . & 85 & 6.8 & 100.0 & 85 & 5.5 \\
\hline $\begin{array}{l}\text { Subtotal cultivos } \\
\text { permanentes }\end{array}$ & 222 & 75.2 & 22.3 & 775 & 61.7 & 77.7 & 997 & 64.3 \\
\hline Maíz & . & . & . & 53 & 4.2 & 100.0 & 53 & 3.4 \\
\hline $\begin{array}{l}\text { Otros de ciclo } \\
\text { corto }\end{array}$ & . & . & . & 55 & 4.4 & 100.0 & 55 & 3.6 \\
\hline Рapa & . & . & . & 13 & 1.0 & 100.0 & 13 & 0.8 \\
\hline Yuca & 55 & 18.7 & 15.9 & 291 & 23.2 & 84.1 & 346 & 22.3 \\
\hline $\begin{array}{l}\text { Subtotal cultivos } \\
\text { de ciclo corto }\end{array}$ & 55 & 18.7 & 11.8 & 412 & 32.8 & 88.2 & 467 & 30.1 \\
\hline $\begin{array}{l}\text { Otros cultivos } \\
\text { culturales }\end{array}$ & 7 & 2.5 & 14.1 & 45 & 3.6 & 85.9 & 52 & 3.4 \\
\hline Coca/Marihuana & 11 & 3.7 & 30.6 & 25 & 2.0 & 69.4 & 35 & 2.3 \\
\hline $\begin{array}{l}\text { Subtotal cultivos } \\
\text { culturales }\end{array}$ & 18 & 6.2 & 20.8 & 69 & 5.5 & 79.2 & 88 & 5.6 \\
\hline Total & 295 & 100.0 & 19.0 & 1255 & 100.0 & 81.0 & 1551 & 100.0 \\
\hline
\end{tabular}




\section{Anexo VIII. Tipo de abono utilizado según cultivos principales y complementarios, Encuesta Piloto Experimental Nasa}

\section{TIPO DE CULTIVO}

TIPO DE CULTIVO

TIPO DE CULTIVO

\begin{tabular}{|c|c|c|c|c|c|c|}
\hline \multirow{3}{*}{$\begin{array}{l}\text { TIPO DE } \\
\text { CULTIVO }\end{array}$} & \multicolumn{6}{|c|}{ CALDONO } \\
\hline & \multicolumn{3}{|c|}{ Principal } & \multicolumn{3}{|c|}{ Complementario } \\
\hline & $\mathrm{N}$ & $\% \mathrm{Col}$ & $\%$ Fil & $\mathrm{N}$ & $\% \mathrm{Col}$ & $\%$ Fil \\
\hline Orgánico & 352 & 40.0 & 26.3 & 989 & 64.9 & 73.7 \\
\hline Químico & 389 & 44.2 & 87.9 & 54 & 3.5 & 12.1 \\
\hline Combinado & 12 & 1.4 & 23.2 & 41 & 2.7 & 76.8 \\
\hline No usa & 127 & 14.4 & 22.4 & 440 & 28.9 & 77.6 \\
\hline Total & 881 & 100.0 & 36.6 & 1524 & 100.0 & 63.4 \\
\hline
\end{tabular}

Principal Complementario

\begin{tabular}{llllll}
$\mathrm{N}$ & \%Col & \%Fil & $\mathrm{N}$ & \%Col & $\%$ Fil \\
\hline 288 & 38.5 & 6.1 & 4467 & 71.3 & 93.9 \\
214 & 28.6 & 41.0 & 308 & 4.9 & 59.0 \\
169 & 22.6 & 39.7 & 258 & 4.1 & 60.3 \\
76 & 10.2 & 5.9 & 1229 & 19.6 & 94.1 \\
748 & 100.0 & 10.7 & 6262 & 100.0 & 89.3
\end{tabular}

\begin{tabular}{|llllll|}
\hline \multicolumn{7}{c}{} & \multicolumn{3}{c}{ JAMBALÓ } \\
\hline $\mathrm{N}$ & \% Col & \% Fil & $\mathrm{N}$ & \% Col & \% Fil \\
\hline 138 & 18.9 & 20.9 & 522 & 23.4 & 79.1 \\
\hline 124 & 17.1 & 42.1 & 171 & 7.7 & 57.9 \\
\hline 25 & 3.4 & 49.5 & 25 & 1.1 & 50.5 \\
\hline 440 & 60.5 & 22.6 & 1510 & 67.8 & 77.4 \\
\hline 727 & 100.0 & 24.6 & 2229 & 100.0 & 75.4 \\
\hline
\end{tabular}

\section{TORIBÍO}


Anexo IX. Tiempo en horas destinado al trabajo doméstco en la última semana, Encuesta Piloto Experimental Nasa 2014-2015

Hombre Mujer $\square$ Total

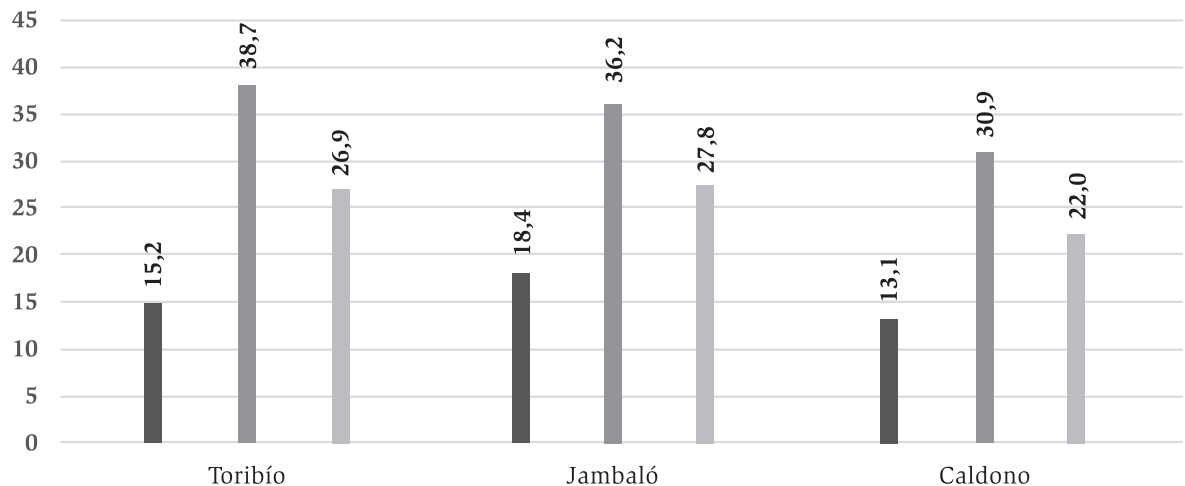

Anexo X. Promedio de semanas de trabajo en la finca dedicadas a los cultivos para la venta en los últimos seis meses, Encuesta Piloto Experimental Nasa 2014-2015

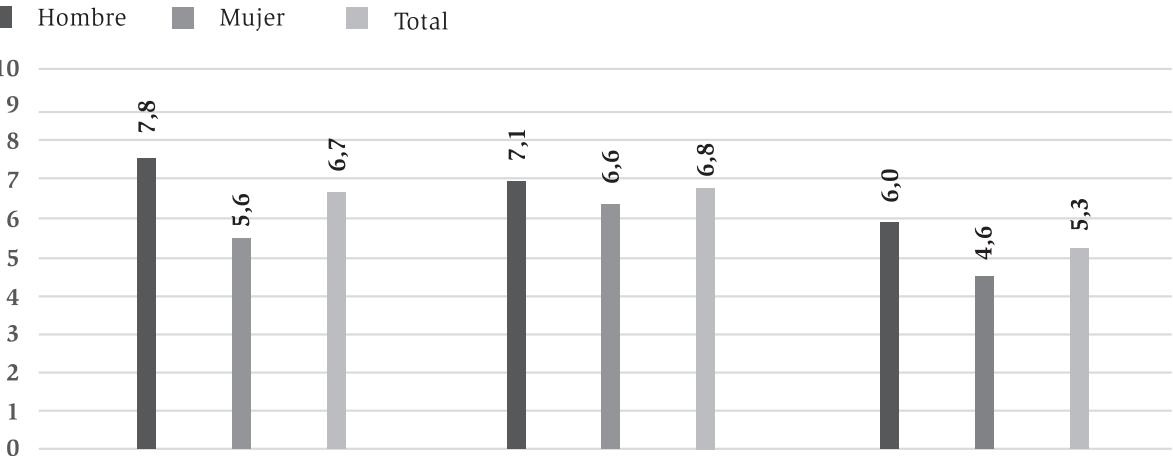

Toribío

Jambaló

Caldono 
Anexo X. Promedio de semanas de trabajo en la finca dedicadas a los cultivos para el autoconsumo en los últimos seis meses, Encuesta Piloto Experimental Nasa 2014-2015

Hombre $\quad$ Mujer $\square$ Total

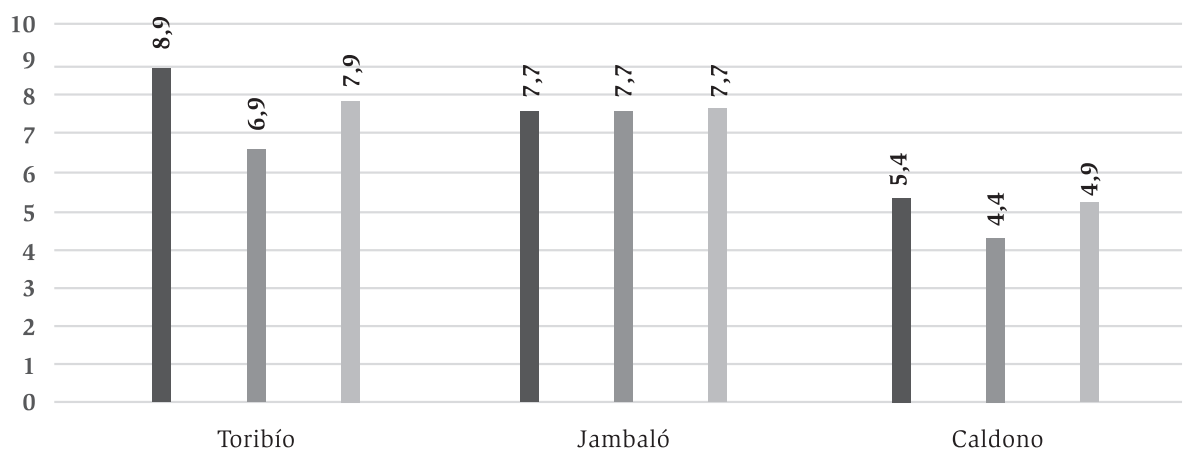

Anexo XI. Distribución de las personas de 5 y más años de edad que en el último mes le dedicaron tiempo al trabajo para la guardia indígena

\begin{tabular}{|c|c|c|c|c|c|c|c|c|}
\hline \multirow{3}{*}{ Sexo } & \multicolumn{8}{|c|}{ JAMBALÓ } \\
\hline & \multicolumn{3}{|c|}{$\mathrm{Si}$} & \multicolumn{3}{|c|}{ No } & \multicolumn{2}{|c|}{ Total } \\
\hline & $\mathrm{N}$ & $\% \mathrm{Col}$ & \% Fil & $\mathrm{N}$ & $\% \mathrm{Col}$ & \% Fil & $\mathrm{N}$ & $\% \mathrm{Col}$ \\
\hline Hombre & 568 & 47.8 & 8.2 & 6332 & 50.6 & 91.8 & 6900 & 50.3 \\
\hline Mujer & 621 & 52.2 & 9.1 & 6194 & 49.5 & 90.9 & 6816 & 49.7 \\
\hline Total & 1189 & 100.0 & 8.7 & 12526 & 100.0 & 91.3 & 13716 & 100.0 \\
\hline
\end{tabular}

\begin{tabular}{|c|c|c|c|c|c|c|c|c|}
\hline \multirow{3}{*}{ Sexo } & \multicolumn{8}{|c|}{ CALDONO } \\
\hline & \multicolumn{3}{|c|}{$\mathrm{Si}$} & \multicolumn{3}{|c|}{ No } & \multicolumn{2}{|c|}{ Total } \\
\hline & $\mathrm{N}$ & $\% \mathrm{Col}$ & $\%$ Fil & $\mathrm{N}$ & $\% \mathrm{Col}$ & $\%$ Fil & $\mathrm{N}$ & $\% \mathrm{Col}$ \\
\hline Hombre & 354 & 29.7 & 6.8 & 4860 & 38.8 & 93.2 & 5213 & 38.0 \\
\hline Mujer & 210 & 17.6 & 3.8 & 5276 & 42.1 & 96.2 & 5486 & 40.0 \\
\hline Total & 564 & 47.4 & 5.3 & 10136 & 80.9 & 94.7 & 10699 & 78.0 \\
\hline
\end{tabular}




\begin{tabular}{|c|c|c|c|c|c|c|c|c|}
\hline \multirow{3}{*}{ Sexo } & \multicolumn{8}{|c|}{ TORIBÍO } \\
\hline & \multicolumn{3}{|c|}{$\mathrm{Si}$} & \multicolumn{3}{|c|}{ No } & \multicolumn{2}{|c|}{ Total } \\
\hline & $\mathrm{N}$ & $\% \mathrm{Col}$ & \% Fil & $\mathrm{N}$ & $\% \mathrm{Col}$ & \%Fil & $\mathrm{N}$ & $\% \mathrm{Col}$ \\
\hline Hombre & 1815 & 152.6 & 12.2 & 13035 & 104.1 & 87.8 & 14850 & 108.3 \\
\hline Mujer & 1074 & 90.3 & 7.2 & 13861 & 110.7 & 92.8 & 14935 & 108.9 \\
\hline Total & 2888 & 242.9 & 9.7 & 26896 & 214.7 & 90.3 & 29785 & 217.2 \\
\hline
\end{tabular}

Anexo XI. Distribución de las personas de 5 y más años de edad que en el último mes le dedicaron tiempo al trabajo para la vereda

\begin{tabular}{|c|c|c|c|c|c|c|c|c|}
\hline \multirow{3}{*}{ Sexo } & \multicolumn{8}{|c|}{ JAMBALÓ } \\
\hline & \multicolumn{3}{|c|}{$\mathrm{Si}$} & \multicolumn{3}{|c|}{ No } & \multicolumn{2}{|c|}{ Total } \\
\hline & $\mathrm{N}$ & $\% \mathrm{Col}$ & $\%$ Fil & $\mathrm{N}$ & $\% \mathrm{Col}$ & $\%$ Fil & $\mathrm{N}$ & $\% \mathrm{Col}$ \\
\hline Hombre & 4065 & 58.9 & 51.5 & 3826 & 56.1 & 48.5 & 7890 & 57.5 \\
\hline Mujer & 2835 & 41.1 & 48.7 & 2990 & 43.9 & 51.3 & 5825 & 42.5 \\
\hline Total & 6900 & 100.0 & 50.3 & 6816 & 100.0 & 49.7 & 13716 & 100.0 \\
\hline
\end{tabular}

\begin{tabular}{|c|c|c|c|c|c|c|c|c|}
\hline \multirow{3}{*}{ Sexo } & \multicolumn{8}{|c|}{ CALDONO } \\
\hline & \multicolumn{3}{|c|}{$\mathrm{Si}$} & \multicolumn{3}{|c|}{ No } & \multicolumn{2}{|c|}{ Total } \\
\hline & $\mathrm{N}$ & $\% \mathrm{Col}$ & $\%$ Fil & $\mathrm{N}$ & $\% \mathrm{Col}$ & \%Fil & $\mathrm{N}$ & $\% \mathrm{Col}$ \\
\hline Hombre & 2681 & 51.4 & 50.5 & 2629 & 47.9 & 49.5 & 5311 & 49.6 \\
\hline Mujer & 2532 & 48.6 & 47.0 & 2857 & 52.1 & 53.0 & 5388 & 50.4 \\
\hline Total & 5213 & 100.0 & 48.7 & 5486 & 100.0 & 51.3 & 10699 & 100.0 \\
\hline
\end{tabular}

\begin{tabular}{|c|c|c|c|c|c|c|c|c|}
\hline \multirow{3}{*}{ Sexo } & \multicolumn{8}{|c|}{ TORIBÍO } \\
\hline & \multicolumn{3}{|c|}{$\mathrm{Si}$} & \multicolumn{3}{|c|}{ No } & \multicolumn{2}{|c|}{ Total } \\
\hline & $\mathrm{N}$ & $\% \mathrm{Col}$ & $\%$ Fil & $\mathrm{N}$ & $\% \mathrm{Col}$ & $\%$ Fil & $\mathrm{N}$ & $\% \mathrm{Col}$ \\
\hline Hombre & 6270 & 58.4 & 42.2 & 8580 & 45.0 & 57.8 & 14850 & 49.9 \\
\hline Mujer & 4458 & 41.6 & 29.9 & 10470 & 55.0 & 70.1 & 14928 & 50.1 \\
\hline Total & 10728 & 100.0 & 36.0 & 19050 & 100.0 & 64.0 & 29778 & 100.0 \\
\hline
\end{tabular}

